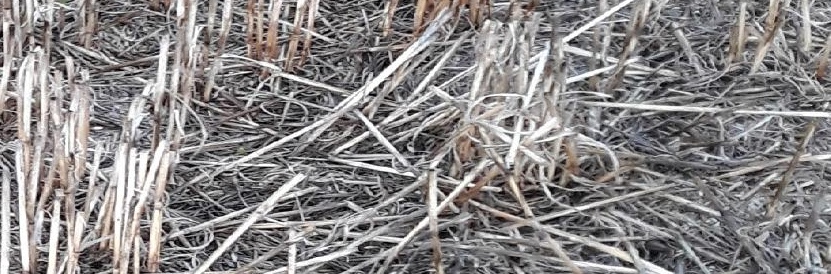

\title{
Opzet voor een Bodemmaatlat 0.1
}

G.H. Ros, J.J. de Haan, L. Molendijk 


\title{
Opzet voor een Bodemmaatlat 0.1
}

G.H. Ros ${ }^{1,2,3}$, J.J. de Haan ${ }^{1}$, L. Molendijk ${ }^{1}$

\author{
1 Wageningen University \& Research \\ 2 Nutriënten Management Instituut \\ 3 Stichting Open Bodemindex
}

Dit onderzoek is in opdracht van de Topsector Agri \& Food uitgevoerd door de Stichting Wageningen Research (WR), in het kader van de PPS Beter Bodembeheer (TKI-AF-16064/BO-56-001-005).

WR is een onderdeel van Wageningen University \& Research, samenwerkingsverband tussen Wageningen University en de Stichting Wageningen Research.

Wageningen, juli 2021

Rapport WPR-892 
Ros, G.H., de Haan J.J., L. Molendijk, 2021. Opzet voor een Bodemmaatlat 0.1. Wageningen Research, Rapport WPR-892. 30 blz.

Dit rapport is gratis te downloaden op https://doi.org/10.18174/551036

(C) 2021 Wageningen, Stichting Wageningen Research, Wageningen Plant Research, Business unit XXXXX, Postbus 16, 6700 AA Wageningen; T 03174807 00; www.wur.nl/plant-research

KvK: 09098104 te Arnhem

VAT NL no. 8113.83.696.B07

Stichting Wageningen Research. Alle rechten voorbehouden. Niets uit deze uitgave mag worden verveelvoudigd, opgeslagen in een geautomatiseerd gegevensbestand, of openbaar gemaakt, in enige vorm of op enige wijze, hetzij elektronisch, mechanisch, door fotokopieën, opnamen of enige andere manier zonder voorafgaande schriftelijke toestemming van Stichting Wageningen Research.

Stichting Wageningen Research is niet aansprakelijk voor eventuele schadelijke gevolgen die kunnen ontstaan bij gebruik van gegevens uit deze uitgave.

Rapport WPR-892 


\section{Inhoud}

\section{Inhoud}

Inhoud

$\begin{array}{lr}\text { Samenvatting } & \mathbf{5}\end{array}$

1

$\begin{array}{ll}\text { Achtergrond en aanleiding } & 7\end{array}$

2

$\begin{array}{ll}\text { Meetbaar maken van bodemkwaliteit } & 9\end{array}$

2.1 Beoordeling bodemkwaliteit 9

$\begin{array}{ll}2.2 \text { Definities } & 10\end{array}$

3

$\begin{array}{ll}\text { Bodemmaatlat } 0.1 & 12\end{array}$

3.1 Afbakening $\quad 12$

3.2 De zuurgraad $\quad 12$

3.3 De fosfaattoestand en -beschikbaarheid 14

$\begin{array}{lll}3.4 & \text { De kaliumtoestand en -beschikbaarheid } & 15\end{array}$

$\begin{array}{lll}3.5 & \text { Het stikstofleverend vermogen } & 18\end{array}$

$\begin{array}{lll}3.6 & \text { Het watervasthoudend vermogen } & 20\end{array}$

$\begin{array}{lll}3.7 & \text { Ondersteunende bodemkenmerken } & 21\end{array}$

$\begin{array}{ll}3.7 .1 \text { Textuur } & 21\end{array}$

$\begin{array}{ll}3.7 .2 \text { Organische stof } & 21\end{array}$

$\begin{array}{ll}\text { 3.7.3 Droge bulkdichtheid } & 22\end{array}$

$4 \quad$ Vooruitblik $r 24$

$\begin{array}{lr}\text { Literatuur } & 25\end{array}$ 



\section{Samenvatting}

De BO-Akkerbouw heeft vanuit het Actieplan Plantgezondheid de PPS Beter Bodembeheer gevraagd om een opzet te maken voor een 'Bodemmaatlat' waarmee boeren eenvoudig hun bodemkwaliteit kunnen monitoren. Uitgangspunten voor de maatlat zijn:

- $\quad$ Aansluiting op de BLN, versie 1.0 bodemindicatorenset;

- Aansluiting op gangbare bedrijfsmanagementsystemen;

- Toepasbaar door boeren op korte termijn en daar bewustwording genereert en advies geeft over tenminste no-regret maatregelen;

- Beginnen bij wat makkelijk kan en dat verder uitbouwen.

De voorliggende rapportage beschrijft de uitwerking van het concept van de bodemmaatlat.

Vijf bodemindicatoren zijn geselecteerd en drie perceelskenmerken die nodig zijn om de kwaliteit van de bodem in beeld te brengen in relatie tot een streefwaarde (zie bijlage 1). Dit zijn achtereenvolgens:

Indicatoren:

1. De zuurgraad;

2. De fosfaattoestand (lees: leveren en bufferen van fosfaat)

3. De kaliumtoestand (lees: leveren en bufferen van kalium);

4. Het stikstofleverend vermogen;

5. Het watervasthoudend vermogen;

Bodemkenmerken:

1. Textuur;

2. Organische stofgehalte;

3. Droge bulkdichtheid;

De verschillende bodemindicatoren zijn in de rapportage uitgewerkt. Voor elke indicator wordt een korte inhoudelijke toelichting gegeven op de relevantie ervan, de benodigde metingen als ook het beoordelingskader en onderliggende onderbouwing.

Op basis van het resultaat van dit rapport heeft de BO-Akkerbouw besloten niet verder te gaan met de ontwikkeling van de Bodemmaatlat maar aan te sluiten bij de integrale systematiek van meten en beoordelen zoals dat binnen PPS Beter Bodembeheer wordt uitgewerkt voor BLN, versie 2.0 en de Open Bodemindex. De voorgestelde bodemmaatlat biedt op dit moment te weinig extra's ten opzichte van de al beschikbare tools. 


\section{$1 \quad$ Achtergrond en aanleiding}

Zowel het ministerie van Landbouw, Natuur en Voedselkwaliteit (kamerbrief van mei 2018), als private partijen (in het Nationaal Programma Landbouwbodems) hebben als streefdoel aangegeven dat alle landbouwbodems in Nederland in 2030 duurzaam worden beheerd. In veel beleidsopgaven is de bodemkwaliteit en een goed bodembeheer essentieel voor het slagen van het beleid. Voorbeelden van recent beleid waarin bodembeheer een belangrijke rol heeft zijn:

- het Nationaal Programma Landbouwbodems,

- de visie rond kringlooplandbouw LNV,

- het Nederlands klimaatakkoord,

- het 6e actieprogramma nitraat met herijking mestbeleid en

- de Kaderrichtlijn water.

Ook internationaal speelt dit o.a. met het klimaatakkoord van Parijs en de Farm to Fork Strategy van de EU en specifiek daarin de Mission Board Soil and Food. Voor het bedrijfsleven is bodembeheer ook van groot belang voor een robuust toekomstgericht teeltsysteem met grote weerbaarheid tegen ziekte en plagen en een goed opbrengstpotentieel en verdienmodel.

Om na te gaan of bodems duurzaam beheerd worden en de huidige goede bodemkwaliteit voor toekomstige generaties behouden blijft, is het nodig om de ontwikkeling in bodemkwaliteit vast te stellen. Hiervoor moet de bodemkwaliteit én gemeten én beoordeeld worden. Alleen op basis van betrouwbare en zinvolle metingen kan beoordeeld worden wat de kwaliteit is en welke maatregelen nodig zijn om de bodemkwaliteit te behouden of verbeteren. Het is belangrijk dat daarbij een gemeenschappelijke, eenduidige werkwijze gebruikt wordt.

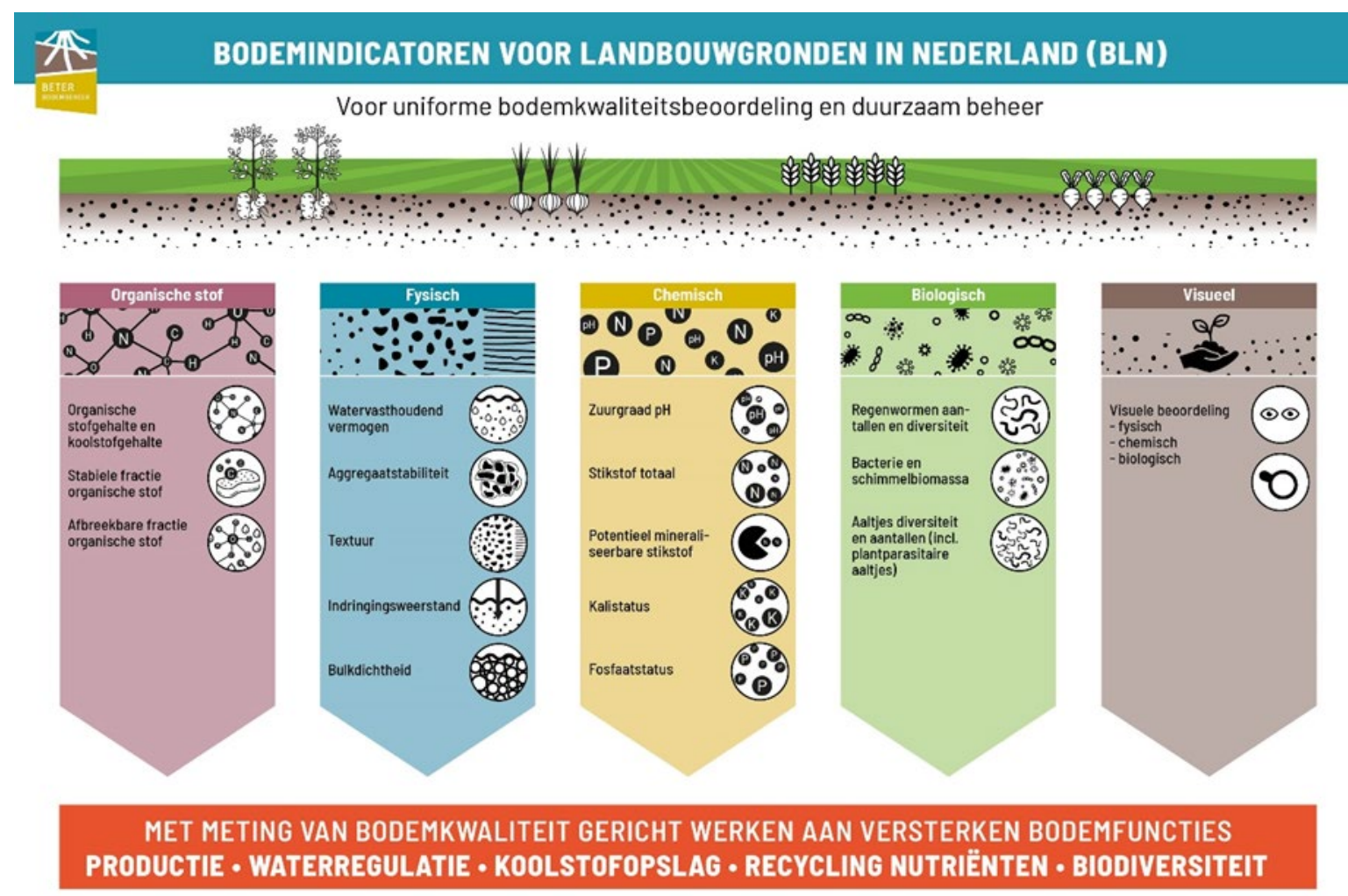

Figuur 1.1 Gewenste bodemkwaliteitsindicatoren voor meten en beoordelen van bodemkwaliteit.

Wageningen University \& Research heeft daarvoor in 2019 de indicatorset Bodemindicatoren voor Landbouwgronden in Nederland (BLN, versie 1.0) ontwikkeld in opdracht van het Ministerie van LNV (Hanegraaf et al., 2019). Tegelijkertijd hebben de verschillende kennisinstellingen in Nederland (WUR, Deltares, KWR, NIOO) samen met de praktijk gewerkt aan een beoordelingssystematiek van de kwaliteit 
van landbouwbodems (Ros, 2019), uitmondend in het framework van de Open Bodemindex (OBI). Hierbij wordt voortgebouwd op bestaande metingen zoals deze beschikbaar zijn via routinematig landbouwkundig bodemonderzoek. Zowel de meetset BLN 1.0 als de systematiek van de OBI worden door de partijen in het Nationaal Programma Landbouwbodems onderschreven. Daarmee is een belangrijke stap gezet voor het eenduidig bepalen en beoordelen van de bodemkwaliteit van landbouwbodems en te komen tot duurzaam beheerde landbouwbodems.

Zowel de BLN als de OBI hebben een integrale blik en integreren data en metingen van verschillende bronnen. BO-Akkerbouw heeft vanuit het Actieplan Plantgezondheid aan de PPS Beter Bodembeheer gevraagd om een eerste selectie van indicatoren uit de BLN, versie 1.0 te maken die akkerbouwers zelf eenvoudig kunnen toepassen op hun bedrijf in combinatie met de bedrijfsmanagementgegevens die de boer al heeft om zo de bewustwording bij boeren rond bodembeheer en het monitoren van bodemkwaliteit te vergroten.

Uitgangspunten voor de maatlat zijn:

- $\quad$ Aansluiting op de BLN, versie 1.0 bodemindicatorenset;

- Aansluiting op gangbare bedrijfsmanagementsystemen;

- Toepasbaar door boeren op korte termijn en daar bewustwording genereert en advies geeft over tenminste no-regret maatregelen;

- Beginnen bij wat makkelijk kan en dat verder uitbouwen.

De voorliggende rapportage beschrijft de uitwerking van het concept van de bodemmaatlat. Daadwerkelijke omzetting naar een bruikbaar instrument (applicatie) valt hierbuiten. 


\section{Meetbaar maken van bodemkwaliteit}

\subsection{Beoordeling bodemkwaliteit}

Vanuit de bodem bekeken wordt de kwaliteit van de bodem bepaald door het klimaat, het moedermateriaal (de ondergrond), de topografie en het landschap, de flora en fauna in het verleden en het beheer van de bodem en het omliggende watersysteem. De kwaliteit van die bodem kan beschreven worden via de diverse fysische, chemische en biologische eigenschappen en functies die de bodem levert. Bij voorkeur wordt bij het beoordelen van de bodemkwaliteit op basis van doelstellingen ook rekening gehouden met de potentie van de bodem vanuit de bovengenoemde fysische omstandigheden en het beheer in het verleden. Er is geen eenduidig meetinstrument beschikbaar dat op ieder willekeurig moment de kwaliteit van de bodem met een eenvoudige representatieve en betaalbare methode inzichtelijk kan maken. De kwaliteit van de bodem kan worden gedefinieerd als "de capaciteit van de bodem om te functioneren als een vitaal levend systeem, binnen de grenzen van het ecosysteem en het landgebruik, om de productiviteit van planten en dieren in stand te houden of te verbeteren, de wateren luchtkwaliteit te verbeteren, en het bevorderen van de gezondheid van planten en dieren". Let wel, er zijn ook andere doelen te definiëren waarbij gewerkt wordt doelen voor primaire productie, waterregulatie en zelfreinigend vermogen, koolstof vastlegging en regulatie, leveren van functionele en intrinsieke biodiversiteit en de kringloop dan wel het leveren van nutriënten. Dit betekent dus dat de doelen waar de bodem met zijn beheer aan moet bijdragen enkel- en meervoudig zijn en sterk kunnen variëren.

Duurzaam Bodembeheer kan worden als volgt worden gedefinieerd: "bodembeheer is duurzaam als de ondersteunende, voorzienende, regulerende en culturele diensten die door de bodem worden geleverd, worden gehandhaafd of verbeterd zonder de bodemfuncties die deze diensten mogelijk maken of de biodiversiteit significant te schaden. Het evenwicht tussen de ondersteunende en bevoorradingsdiensten voor plantaardige productie en de regulerende diensten die de bodem levert voor waterkwaliteit en beschikbaarheid en voor de samenstelling van broeikasgassen in de atmosfeer is een bijzondere zorg (FAO, 2017)". In het kader van de huidige studie beperkt deze definitie zich tot landbouwgronden en landbouwproductie.

Om een zinnige uitspraak te doen over de kwaliteit van de bodem zijn metingen cruciaal. Hiervoor is in de afgelopen jaren de indicatorset Bodemindicatoren voor Landbouwgronden in Nederland (BLN) ontwikkeld. Voor de uitspraak "de kwaliteit van deze bodem is goed" of "deze bodem is goed beheerd" moet elke meting echter ook worden geïnterpreteerd in het licht van een gewenste situatie, een zogenoemde streefwaarde. De mate waarin het gemeten bodemkenmerk afwijkt van een streefwaarde zegt namelijk iets over hoe 'goed' het relevante bodemkenmerk aansluit bij een gewenste situatie, een situatie die wordt nagestreefd (vandaar ook de term "streefwaarde"). In de wetenschappelijke literatuur volgt deze waardering (als het gaat over bodemkwaliteit) altijd één van de volgende drie patronen: "meer is beter", "minder is beter" of "er is een optimum". Een meting zonder een onderbouwde koppeling met een "streefwaarde" geeft geen informatie. Als er meerdere metingen worden gedaan, dan kun je de metingen onderling uiterwaard wel vergelijken (ook wel referentiewaarde genoemd), maar het blijft onbekend of de bodem daardoor beter of slechter geschikt is om zijn functies uit te voeren.

Elk goed bodemwaarderingsinstrument dat zinvolle informatie geeft aan boeren om gericht te werken aan een goede bodemkwaliteit, als ook het duurzaam beheer van de bodem, volgt ten principale vier opeenvolgende stappen (Figuur 2.1; Rinot et al., 2019):

1. Vaststellen van één of meerdere doelen waar de bodem met zijn beheer aan moet bijdragen;

2. Selectie, meting en voorbewerking van bodemkenmerken die van invloed zijn op deze doelen;

3. Evaluatie of waardering van de individuele bodemkenmerken, gegeven deze doelen (elk perceel en elke functie heeft een eigen "distance to target"), en;

4. Integratie van deze bodemkenmerken in een gewogen index, waarbij de geëvalueerde bodemfunctie functioneert als een kritische prestatie indicator; het brengt namelijk de bodemkwaliteit in beeld in relatie tot een gewenste situatie. 
Om de bodemkwaliteit te kunnen beoordelen is allereerst een keuze nodig voor welk doel de bodem moet (of kan) worden gebruikt. Het is namelijk onmogelijk om de intrinsieke kwaliteit van een bodem te beoordelen los van het landgebruik (stap 1 in Figuur 2-1). Een bodem die gebruikt wordt voor natuurontwikkeling of weidevogelbeheer heeft een andere kwaliteit nodig dan een bodem die gebruikt voor ruwvoerproductie of gewassen voor menselijke consumptie. Zowel de OBI als de BLN zijn ontwikkeld voor landbouwbodems, wat betekent dat de bodem in eerste instantie beoordeeld wordt voor een optimaal en duurzaam landbouwkundig gebruik.

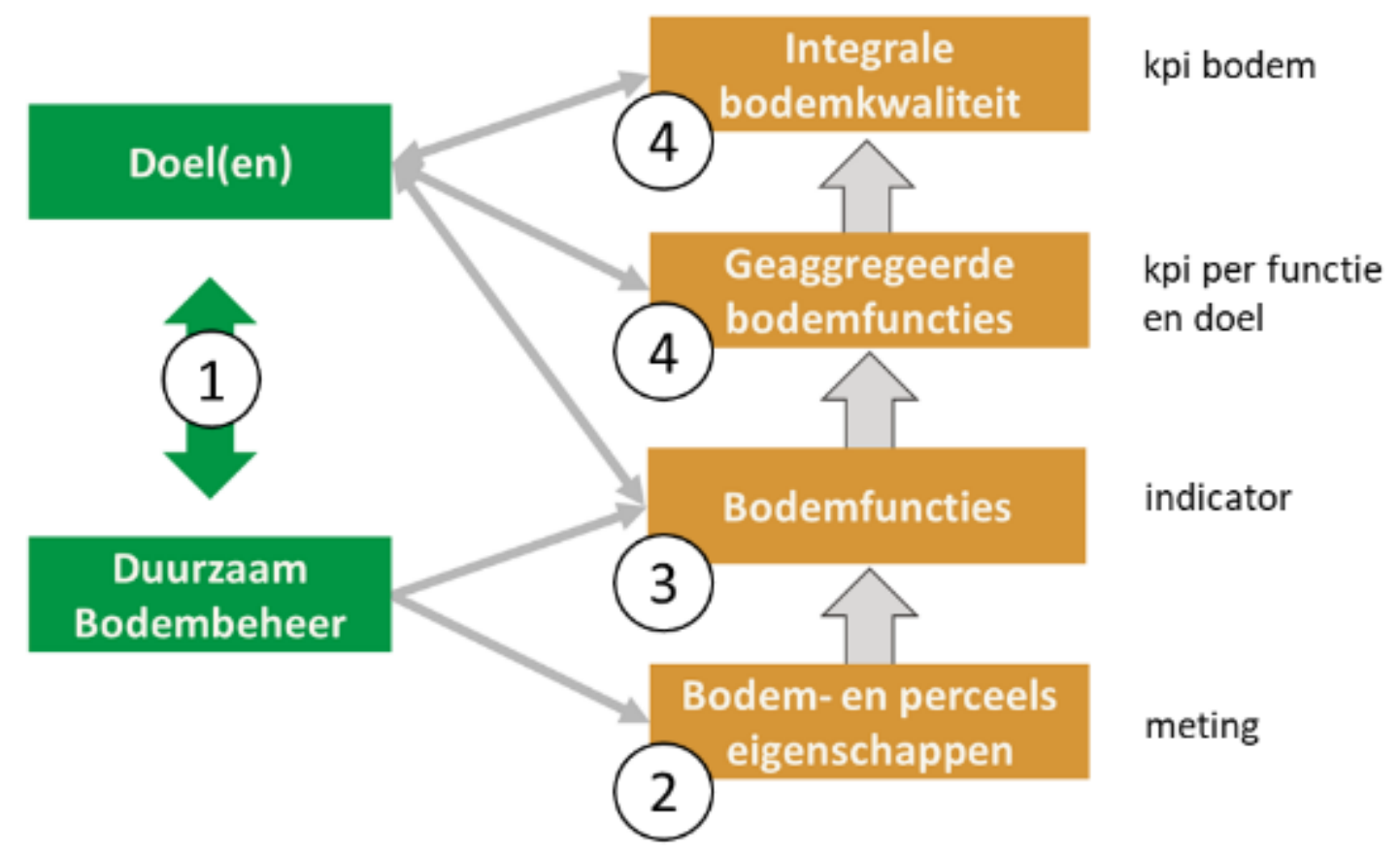

Figuur 2.1 Conceptuele aanpak van meten en beoordelen van bodemkwaliteit.

Duurzaam bodembeheer op landbouwbodems houdt ook concreet in dat er aandacht is voor doelen buiten het primaire belang van landbouwkundige productie. Zowel het directe belang van de landeigenaar (boer of verhuurder) als het principe om afwenteling naar elders en later te voorkomen, maken dat duurzaam bodembeheer op meerdere schaalniveaus moet worden ingevuld. De opgaves en uitdagingen zijn per regio anders en er liggen ook opgaves die niet direct in lijn liggen met een duurzame landbouwbodem vanuit het huidige productieperspectief.

Omdat deze studie de kwaliteit in beeld wil brengen van een select aantal bodemmetingen en indicatoren is het onmogelijk om een integraal beeld weer te geven van de kwaliteit van de landbouwbodem. Een inhoudelijke beschrijving van geaggregeerde bodemfuncties (stap 4 in figuur 2.1) of de ontwikkeling van een kritische prestatie indicator voor bodemkwaliteit valt daarom buiten de inhoud van deze publicatie. Voor meer informatie verwijzen we graag naar de publicaties van de Haan \& Ros (2019), Ros (2010) en Rinot et al. (2019).

\subsection{Definities}

Binnen het werkveld van bodemwaardering worden allerlei begrippen en definities door elkaar heen gebruikt. Een heldere definitie van begrippen is daarom belangrijk. In dit rapport maken hierbij gebruik van de volgende definities:

- Bodemkwaliteit: de capaciteit van een bodem om onder wisselende omstandigheden de gewenste bodemfuncties in voldoende mate beschikbaar te hebben voor een combinatie van doelen (en diensten) zoals voedselproductie, efficiënte kringloop van voedingsstoffen en behoud van biodiversiteit.

- Bodemdiensten: de verschillende ecosysteemdiensten die de bodem kan leveren. Dit zijn onder andere de primaire (landbouwkundige) productie van gewassen, koolstofvastlegging, 
waterzuivering en retentie van nutriënten in de bodem, biodiversiteit en het in standhouden van de kringlopen van nutriënten.

- Bodemfuncties: de rol van de bodem in het vervullen van bepaalde doelstellingen en bodemdiensten. Onderscheid wordt gemaakt in type bodemfuncties: productie-, draag-, regulatie- en informatiefunctie. Zo zijn nutriëntenlevering, bodemstructuur en bodemgezondheid belangrijke bodemfuncties voor het realiseren van de ecosysteemdienst 'primaire productie'.

- Bodemindicatoren: een waarde of index waarmee de bijdrage dan wel relevantie van een bodemfunctie wordt beoordeeld. Dit gebeurt in de praktijk via waarderingsklassen (laag tot hoog) ofwel cijfers (1-10). Dit betekent ook dat een bodemmeting op zichzelf geen indicator is. Een bodemanalyse kan wel input zijn voor het berekenen van een bodemfunctie, en deze bodemfunctie kan vervolgens gebruikt worden als een indicator.

- Bodemeigenschap: een kenmerk van een bodem dat indicatief kan zijn voor één of meerdere bodemfuncties. Deze eigenschappen kunnen zijn geanalyseerd in het laboratorium als ook samenhangen met kenmerken die voortkomen uit de ligging van het perceel in het landschap. Denk bijvoorbeeld aan de grondwatertrap, de variatie in maaiveldhoogte, de helling, en de aanwezigheid van drainage.

- Bodembeheer: maatregelen die de landgebruiker kan nemen om de bodemkwaliteit te verbeteren dan wel aan te passen voor een specifiek doel. Hiermee wordt directe invloed uitgeoefend op (meetbare) bodemeigenschappen, waarbij het effect op zowel op korte als lange termijn zichtbaar kan worden. Een duurzaam bodembeheer kan worden gedefinieerd als het gebruik van de bodem voor de productie van goederen om aan veranderende menselijke behoeften te voldoen, terwijl tegelijkertijd het lange termijn productieve potentieel van deze hulpbron en het onderhoud van haar milieufuncties wordt gewaarborgd.

- Streefwaarde: De waarde voor een indicator waarboven en/of waaronder het gewenste doel bereikt kan worden voor een gegeven combinatie van landgebruik en bodemtype. De streefwaarde kan ook een bandbreedte omvatten. Voorbeelden van doelen zijn 'optimale gewasopbrengst' of 'koolstofvastlegging'.

- Referentiewaarde: Een vastgestelde waarde of bereik waarmee een meetresultaat kan worden vergeleken, zonder oordeelsvorming in termen van goed of slecht voor een gegeven combinatie van landgebruik en bodemtype. 


\section{$3 \quad$ Bodemmaatlat 0.1}

\subsection{Afbakening}

Op basis van een aantal selectiecriteria zijn door BO-Akkerbouw een aantal bodemanalysemethoden en indicatoren geselecteerd als startpunt voor een integrale beoordeling van de bodemkwaliteit. De metingen zijn geselecteerd vanuit de integrale set van de BLN (Hanegraaf et al., 2019), op basis van bestaande kennis over de beoordeling van deze indicatoren (Ros, 2019) en aanvullend op basis van onderstaande selectiecriteria:

- Doelgericht: de metingen zeggen iets over de bodemkwaliteit in de landbouw en de te vervullen bodemfuncties. We gaan ervanuit dat alle indicatoren doelgericht zijn.

- De metingen zijn goed (betrouwbaar), goedkoop en snel te bepalen.

- De metingen (dan wel indicatoren) zijn veranderbaar door management: in hoeverre kan een boer de indicatorwaarde aanpassen door maatregelen te nemen in zijn bedrijfsvoering.

- Er zijn streefwaarden en referentiewaarden beschikbaar voor elk type landgebruik en grondsoort in Nederland. Streefwaarden geven een oordeel wat 'goed' en 'fout' is in relatie tot een "distance to target" en referentiewaarden geven aan wat de meest voorkomende waarden zijn in vergelijkbare landbouwbodems.

Op basis van deze indicatoren zijn vijf bodemindicatoren geselecteerd en drie perceelskenmerken die nodig zijn om de kwaliteit van de bodem in beeld te brengen in relatie tot een streefwaarde (zie bijlage 1. Dit zijn achtereenvolgens:

Indicatoren:

1. De zuurgraad;

2. De fosfaattoestand (lees: leveren en bufferen van fosfaat)

3. De kaliumtoestand (lees: leveren en bufferen van kalium);

4. Het stikstofleverend vermogen;

5. Het watervasthoudend vermogen;

Bodemkenmerken:

1. Textuur;

2. Organische stofgehalte;

3. Droge bulkdichtheid;

De verschillende bodemindicatoren worden in de volgende secties verder uitgewerkt. Voor elke indicator wordt een korte inhoudelijke toelichting gegeven op de relevantie ervan, de benodigde metingen als ook het beoordelingskader en onderliggende onderbouwing.

\subsection{De zuurgraad}

De $\mathrm{pH}$ is een maat voor de zuurgraad van de bodem en wordt in Nederland gebaseerd op een meting in een $0.01 \mathrm{M} \mathrm{CaCl}_{2}$ of $1 \mathrm{M} \mathrm{KCl}$ extract. De $\mathrm{pH}$ is van invloed op de bodemkwaliteit en gewasgroei, onder andere via het effect op de beschikbaarheid van nutriënten en (zware) metalen en de activiteit van het bodemleven. Ook heeft de $\mathrm{pH}$ een effect op de bodembiodiversiteit. Daarnaast wordt de opname van nutriënten door de wortels geremd bij lagere $\mathrm{pH}^{\prime}$ s doordat de wortels bezet raken met $\mathrm{H}^{+}$en bij $\mathrm{pH}^{\prime} \mathrm{s}$ lager dan 4.5 met $\mathrm{Al}^{3+}$ ionen. De gevoeligheid voor met $\mathrm{Al}^{3+}$ verschilt tussen gewassen en cultivars. De optimale $\mathrm{pH}$ van de bodem voor gewasgroei verschilt per gewas. Aardappelen hebben daarbij een voorkeur voor een lagere $\mathrm{pH}$ terwijl granen, mais, suikerbieten en vollegrondsgroenten een voorkeur hebben voor een hogere $\mathrm{pH}$. Op lichtere gronden ( $<25 \%$ lutum) neemt het risico van schurft bij aardappelen toe bij bekalking. In de bekalkingsadviesschema's in de adviesbasis bemesting voor akkerbouw (CBAV, 2020) wordt bij het vaststellen van de streefwaarden voor de te bereiken $\mathrm{pH}$ dan ook onderscheid gemaakt naar grondsoort en bouwplan. Het bekalkings-advies voor grasland is eenvoudiger van opzet. 
Om de zuurgraad van de bodem te beoordelen, wordt er rekening gehouden met de volgende factoren:

- $\quad$ bodemtype (duinzand/dekzand/zeeklei/rivierklei/maasklei/dalgrond/klei/veen/loss);

- landgebruik: grasland, mais of akkerbouw;

- aandeel fabrieksaardappelen in bouwplan;

- $\mathrm{pH}$ : gemeten in $0.01 \mathrm{M} \mathrm{CaCl}_{2}$. Dit kan omgerekend worden naar $\mathrm{pH}-\mathrm{KCl}$;

- $\quad$ het organische stofgehalte (\%)

De standaard methodiek voor het meten van de $\mathrm{pH}$ is een analyse van de $\mathrm{pH}$ in een $0.01 \mathrm{M} \mathrm{CaCl}_{2}$ extract. In geval de zuurgraad is gemeten als $\mathrm{pH}-\mathrm{KCl}$ dan kan deze worden omgerekend naar $\mathrm{pH}-\mathrm{CaCl}_{2}$ volgens Handboek bodem en bemesting (CBAV, 2019):

$$
\mathrm{pH}-\mathrm{CaCl}_{2}=0,9288 * \mathrm{pH}-\mathrm{KCl}+0,5262
$$

Vanuit de bemestingsadviezen zijn waarderingsklassen voor $\mathrm{pH}$ opgesteld, met daarin correcties voor het percentage organische stof en lutum. Voor de akkerbouw zijn deze opgenomen in Handboek bodem en bemesting (CBAV, 2021) en voor grasland en voedergewassen in de Bemestingsadviesbasis (CBGV, 2021). Hieruit blijkt dat:

- $\quad$ Organische stof vermindert het negatieve effect van de $\mathrm{pH}$ op gewasgroei.

- $\quad$ Bij zandgronden met een organisch stofgehalte van $15 \%$ kan de streefwaarde voor $\mathrm{pH}$ een halve eenheid lager liggen dan bij lage gehalten organische stof.

- Bij kleigronden is de gewenste zuurgraad hoger dan op zandgronden. Bij een lutum percentage boven de 10 ligt de gewenste $\mathrm{pH}$ een halve eenheid hoger dan bij lage lutumpercentages.

De bodemzuurgraad is beoordeeld op basis van de vraag of de $\mathrm{pH}$ te hoog of te laag is ten opzichte van de optimale pH-waarde (Van Schöll et al., 2019). De optimale pH-waarde is afhankelijk van de bouwplannen, grondsoort en het organische stofgehalte. Zie onderstaand schema voor een overzicht (Figuur 2.2).

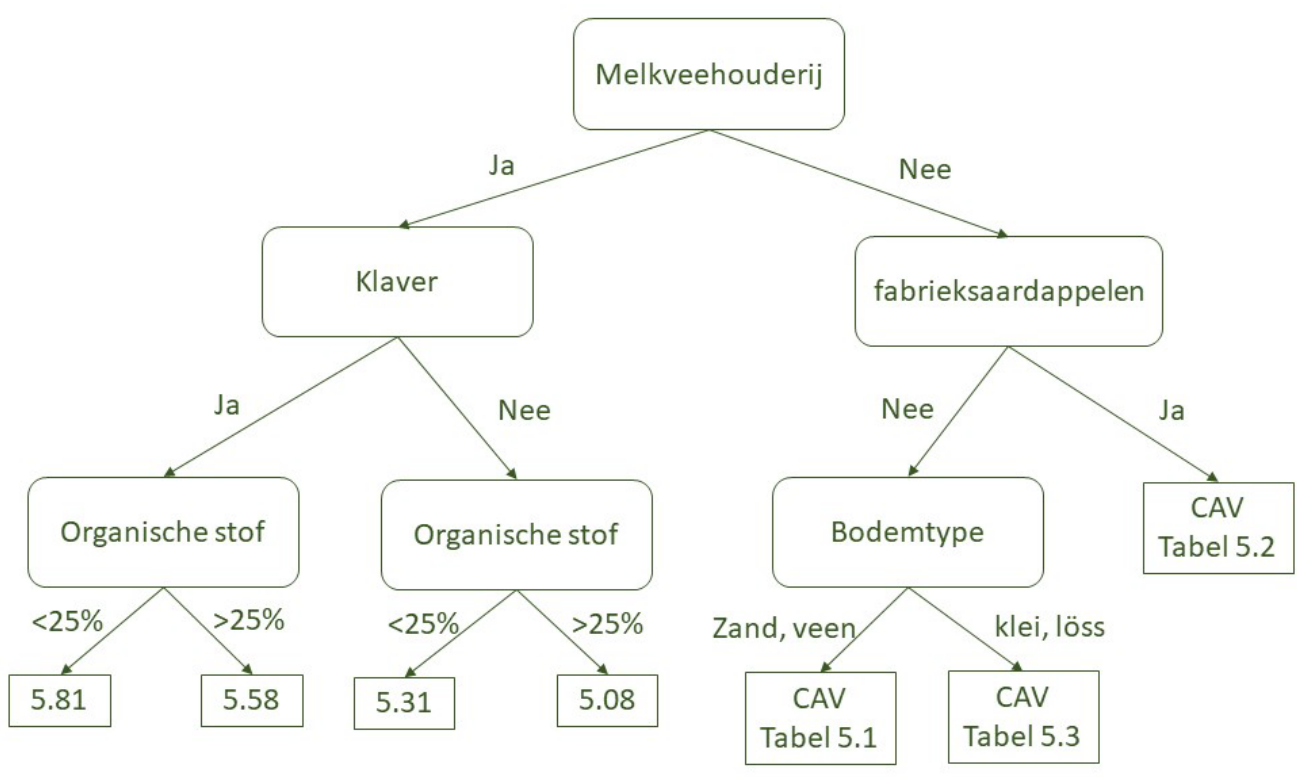

Figuur 2.2 Schema voor het toewijzen van een optimale waarde van $\mathrm{pH}-\mathrm{CaCl}_{2}(\mathrm{CBAV}, 2021)$.

De optimale $\mathrm{pH}$-waarden zijn voor de akkerbouw uitgesplitst naar bouwplannen, afhankelijk van aandeel (fabrieks)aardappelen, het gehalte aan organische stof en grondsoort CBAV, 2021). De optimale pH voor de fabrieksaardappelteelt (vooral dalgrond) is lager bij hoger organische stofgehalte, lager bij een hoger aandeel aardappelen, en hoger bij een hoger aandeel suikerbieten. Hetzelfde geldt voor andere akkerbouw op zandgrond en veengrond. Bij kleigrond hangt de optimale $\mathrm{pH}$ af van organische stofgehalte en lutumgehalte.

In de melkveehouderij is de waardering van de $\mathrm{pH}$ voor alle minerale gronden gelijk (CBGV, 2021). De middelste waarden van de klasse "goed" zijn opgenomen als de optimale pH (d.w.z. pH-KCl = 5.15 voor 
grasland op niet-veengronden, 4.9 voor grasland op veengronden). Deze optimale $\mathrm{pH}-\mathrm{KCl}$ waarden zijn omgerekend naar $\mathrm{pH}_{-} \mathrm{CaCl}_{2}$ waarden met de hierboven beschreven formule. Voor veengronden is de waardering van de $\mathrm{pH}$ ongeveer $0.2 \mathrm{pH}$-eenheid lager. Voor grasland met klaver is de optimale $\mathrm{pH}$ een halve eenheid hoger vastgesteld.

Gemiddeld wordt er eens per vier jaar grondonderzoek uitgevoerd. Bekend is dat de $\mathrm{pH}$ elk jaar met ongeveer 0,05 tot 0,1 pH eenheid daalt (m.u.v. de kalkrijke gronden) met name in de akkerbouw. In teelten waarbij veel organische (drijf)mest wordt gebruikt, zorgt de aanvoer van kationen in de praktijk voor een redelijk neutrale $\mathrm{H}^{+}$-balans waarmee de effecten van verzurende processen worden gecompenseerd. In de waardering van de $\mathrm{pH}$ op akkerbouw zou je de meetwaarde met max. 0,1 pHeenheid kunnen verlagen voor elk jaar na monstername.

\subsection{De fosfaattoestand en -beschikbaarheid}

Fosfaat is een belangrijk nutriënt voor de gewasproductie, en fosfaatbeschikbaarheid is dan ook een belangrijke bodemfunctie. Proeven in de praktijk laten zien dat het effect van een lage fosfaattoestand kan niet geheel kan worden opgeheven door bemesting. Voor de fosfaattoestand van de bodem is daarom een optimaal traject vastgesteld. Enerzijds hoog genoeg om een goede opbrengst te kunnen realiseren. Anderzijds niet onnodig hoog omdat een grote voorraad fosfaat in de bodem niet zinvol is (vanuit het perspectief van kringlooplandbouw én de eindigheid van $\mathrm{P}$ als meststof) en er een hoger risico is voor af- en uitspoeling naar het oppervlaktewater.

In de bodem is fosfaat in diverse vormen aanwezig, zowel in anorganische als organische vorm. De hoeveelheid fosfaat in de bodemoplossing is gering ten opzichte van de totale P-voorraad van de bodem. Anorganisch fosfaat dat in de bodemoplossing aanwezig is, is direct beschikbaar voor opname door de plant. Organisch fosfaat komt pas na afbraak door micro-organismen beschikbaar voor de plant. De niet-opgeloste anorganische en organische P-verbindingen zijn te verdelen in labiele en stabiele verbindingen:

- $\quad$ Het labiele $P$ is in evenwicht met de $P$ in oplossing en is de belangrijkste bron voor nalevering van $\mathrm{P}$ naar de bodemoplossing. Tot de labiele anorganische $\mathrm{P}$-verbindingen behoort $\mathrm{P}$ gebonden aan het oppervlak van ijzer- en aluminium (hydr-)oxiden, en ijzer (Fe), aluminium ( $A l$ ) - en calciumfosfaten. In zure en neutrale gronden wordt de beschikbaarheid van $P$ vooral bepaald door de binding aan Fe- en $\mathrm{Al}$ (hydr-)oxiden. In kalkrijke gronden is $\mathrm{P}$ meestal geassocieerd met calcium (Ca).

- De stabiele P-verbindingen zijn meestal slecht oplosbaar en daardoor ook slecht beschikbaar voor de plant. Tot de stabiele anorganische P-verbindingen behoren onder andere P-houdende bodem-mineralen (bijvoorbeeld apatiet).

De totale hoeveelheid organisch $\mathrm{P}$ in de bodem is sterk afhankelijk van grondsoort, humusgehalte en (historie van) landgebruik en kan variëren van 20 tot meer dan 90 procent van de totale hoeveelheid fosfaat. Planten nemen $\mathrm{P}$ op uit de bodemoplossing gedurende het groeiseizoen. De hoeveelheid $\mathrm{P}$ die direct beschikbaar is in de bodemoplossing is slechts een fractie van de hoeveelheid die een plant in totaal opneemt. Gedurende het groeiseizoen wordt $\mathrm{P}$ nageleverd uit de labiele vorm. Voor de beschikbaarheid is het dus van belang niet alleen de concentratie in bodemoplossing te kennen (de Pintensiteit) maar ook de hoeveelheid die er vanuit de bodem in totaal nageleverd kan worden (de kwantiteit) en de snelheid van nalevering (buffercapaciteit). De nalevering is een functie van zowel de kwantiteit als de intensiteit. Daarnaast is het soort gewas van belang, enerzijds omdat er verschil in Pbehoefte bestaat tussen diverse gewassen en anderzijds doordat er verschillen zijn in de bewortelingskarakteristiek, waardoor het éne gewas gemakkelijker fosfaat kan opnemen uit de bodem dan het andere.

Voor grasland en mais wordt de fosfaattoestand van de bodem geduid op basis van de kwantiteit intensiteit - buffercapaciteit systematiek, zoals deze zijn ontwikkeld op basis van het onderzoek van Rotterdam-Los (2010). Voor de overige gewassen is in 2020 een gewasgericht fosfaatadvies toegevoegd dat ook is gebaseerd is op de combinatie van $\mathrm{P}-\mathrm{CaCl}_{2}$ en $\mathrm{P}-\mathrm{AL}$. Voor het bepalen van de fosfaatstatus 
worden daarom de indicatoren voor het vaststellen van het bemestingsadvies gebruikt. De P-status wordt daarom berekend uit de metingen $\mathrm{P}-\mathrm{AL}, \mathrm{P}-\mathrm{CaCl}_{2}$ en landgebruik.

De fosfaatbeschikbaarheid voor grasland en maisland is geduid op basis van $\mathrm{P}-\mathrm{AL}$ en $\mathrm{P}-\mathrm{CaCl}_{2}$. Daarbij staat $\mathrm{P}-\mathrm{CaCl}_{2}$ voor directe beschikbaarheid en $\mathrm{P}-\mathrm{AL}$ voor de nalevercapaciteit. Beide parameters tellen mee in de gewenste bodemvruchtbaarheid. Bij een hoge P-AL mag voor een optimale bodemvruchtbaarheid de $\mathrm{P}-\mathrm{CaCl}_{2}$ lager zijn dan bij een lagere $\mathrm{P}-\mathrm{AL}$. Andersom mag bij een hoog $\mathrm{P}-\mathrm{CaCl}_{2}$ de $\mathrm{P}-\mathrm{AL}$ lager zijn. De kwantificering van de optimale bodemvruchtbaarheid voor $\mathrm{P}$ is onderbouwd in de CBGVnotitie "Fosfaatstreeftoestand in de bodem voor maïs en gras" (Van Rotterdam en Bussink, 2016). Om een optimale combinatie $\mathrm{P}-\mathrm{CaCl}_{2}-\mathrm{P}$-AL te berekenen is gebruik gemaakt van een combinatieparameter, de P-BeschikbaarheidsIndex (PBI). Deze wordt separaat berekend voor grasland, mais en bouwland.

De volgende formules voor de berekening van PBI worden gebruikt:

- Grasland, PBI $=2+\mathrm{LN}\left(\mathrm{P}-\mathrm{CaCl}_{2}\right) \times(-0.0114 \times \mathrm{P}-\mathrm{AL}+2.5)+0.0251 \times \mathrm{P}-\mathrm{CaCl}_{2}$

- $\quad$ Maisland, $\mathrm{PBI}=\mathrm{P}-\mathrm{CaCl}_{2}+0,05 \times\left(\mathrm{P}-\mathrm{AL} / \mathrm{P}-\mathrm{CaCl}_{2}\right)$

De streeftoestand voor de waarde van PBI is 4 (Tabel 2.1). De streeftoestand voor PBI is voor mais gedefinieerd als de P-beschikbaarheidsindex waarbij een opbrengst van 14,3 ton ds ha-1 bereikt wordt bij een fosfaat-bemesting die overeenkomt met de onttrekking ( $65 \mathrm{~kg} \mathrm{P}_{2} \mathrm{O}_{5} \mathrm{ha}^{-1}$ ) en met een gemiddelde $\mathrm{N}$-gift van $140 \mathrm{~kg}$ werkzame $\mathrm{N} \mathrm{ha}^{-1}$. De streefwaarde van 4 is gebaseerd op de proeven die gebruikt zijn om het bemestingsadvies vast te stellen. De streeftoestand voor grasland is gedefinieerd als de PBI waarbij een P-gehalte in de eerste snede van $3,7 \mathrm{~g} \mathrm{~kg}^{-1}$ kan worden bereikt met een P-gift die gelijk staat aan de onttrekking van de eerste snede. De streeftoestand voor bouwland is gedefinieerd per gewasgroep conform het oude P-waarderingssystematiek waarbij gezocht is naar een P-response als functie van de P-beschikbaarheid (CBAV, 2021). Op dit moment is de waardering van de fosfaattoestand van de bodem voor de akkerbouw (CBAV, 2021) nog gebaseerd op basis van het Pw-getal (volgens van der Paauw, 1970). Verwacht mag worden dat dit zal wijzigen nu in 2022 voor de fosfaatgebruiksnorm wordt overgegaan naar een combinatie van $\mathrm{P}-\mathrm{CaCl}_{2}$ en $\mathrm{P}-\mathrm{AL}$ Deze waardering geldt voor alle grondsoorten.

Tabel 2.1 Beoordeling fosfaattoestand en beschikbaarheid. PBI-bouwland nog voorlopig afhankelijk van invulling fosfaatbodemadvies CBAV.

\begin{tabular}{lccr} 
Fosfaattoestand & PBI-gras & PBI-mais & PBI-bouwland \\
Zeer laag & $<1.5$ & $<1.5$ & 1.5 \\
\hline Laag & $1.5-2.5$ & $1.5-2.5$ & $1.5-2.5$ \\
\hline Voldoende & $2.6-4.0$ & $2.6-4.0$ & $2.6-4.0$ \\
\hline Ruim voldoende & $4.0-4.8$ & $4.0-4.9$ & $4.0-4.9$ \\
\hline (Vrij) hoog & $>4.8$ & $>4.9$ & $>4.9$ \\
\hline
\end{tabular}

Hoog

\subsection{De kaliumtoestand en -beschikbaarheid}

Kalium is evenals $\mathrm{N}$ en $\mathrm{P}$ een belangrijk element voor de gewasgroei. Kalium is in de bodem nagenoeg uitsluitend aanwezig in minerale vorm. Dit is in tegenstelling tot $\mathrm{N}, \mathrm{P}$ en $\mathrm{S}$, die ook in belangrijke mate voorkomen in de organische vorm. De hoeveelheid $\mathrm{K}$ in de bodem kan worden ingedeeld in 4 fracties:

- $\quad \mathrm{K}^{+}$-ionen in de bodemoplossing; geheel en direct beschikbaar voor de plant, maar onvoldoende om de behoefte van het gewas te dekken.

- K-uitwisselbaar; K geadsorbeerd aan de klei- en humusdeeltjes (adsorptiecomplex; CEC). Uitwisseling tussen $\mathrm{K}$ in de bodemoplossing en $\mathrm{K}$ geadsorbeerd vindt snel plaats: binnen enkele minuten tot 24 uur;

- $\quad$ K-gefixeerd of gebonden (kleigronden); de $\mathrm{K}$ die is ingesloten in de kleiplaatjes. Uitwisseling tussen $\mathrm{K}$-gefixeerd met $\mathrm{K}$-bodemoplossing neemt dagen tot maanden in beslag; en 
- $\quad \mathrm{K}$-mineraal of K-gesteente; komt beschikbaar door verwering. De hoeveelheid K die gedurende een groeiseizoen door verwering beschikkaar komt is te klein om voor de landbouw van belang te zijn.

In de bodem is er een dynamische evenwichtssituatie voor de verdeling over de fracties: $\mathrm{K}$ in oplossing, K-uitwisselbaar en K-gefixeerd. Na onttrekking (door gewasopname of uitspoeling) of toevoeging (vanuit bemesting of plantenresten) van $\mathrm{K}$ stelt zich een nieuw evenwicht in waarbij er een herverdeling van $\mathrm{K}$ over de drie fracties plaatsvindt. De hoeveelheid $\mathrm{K}$ in de bodemoplossing wordt zodoende gebufferd door $\mathrm{K}$-uitwisselbaar en K-gefixeerd. Buffering wil zeggen dat bij onttrekking van kalium door de plantenwortel er kalium wordt nageleverd, en bij toedienen van kalium via bemesting de hoge kaliumconcentratie in de bodemoplossing wordt verlaagd door adsorptie. De hoeveelheid K-uitwisselbaar wordt bepaald door:

- de omvang van het adsorptiecomplex; en

- de relatieve bezetting van de CEC (het adsorptiecomplex) met K: Dit wordt beïnvloed door de concentraties van zowel $\mathrm{K}$ als andere kationen (vnl. $\mathrm{Ca}^{2+}, \mathrm{Mg}^{2+}, \mathrm{NH}_{4}{ }^{+}, \mathrm{Na}^{+}$). Deze andere kationen kunnen $\mathrm{K}$ van het adsorptiecomplex verdringen.

Voor het bepalen van de kalistatus worden de indicatoren voor het vaststellen van het bemestingsadvies gebruikt. Voor de akkerbouw was dit altijd het K-getal zoals dat bepaald werd aan de hand van organisch stofgehalte en een extractie in $\mathrm{HCl}$ en oxaalzuur (CBAV, 2021). De extractie wordt anno 2020 niet meer uitgevoerd door laboratoria in Nederland vanwege veiligheidsredenen. Daarnaast wordt op korte termijn het bemestingsadvies voor $\mathrm{K}$ in de akkerbouw aangepast op basis van de $\mathrm{K}$-bezetting van de CEC en de directe beschikbare voorraad $\mathrm{K}$ zoals gemeten met een $0.01 \mathrm{M} \mathrm{CaCl}$-extractie. De klassieke natchemische bepalingsmethode voor K-CEC is een extractie in cobalt hexamine trichloride (ISO 23470, 2018; NEN 6966, 2005) en de alternatieve snelle en goedkope methode is NIRS.

De K-beschikbaarheid en de relatie ervan wordt beïnvloed door bodemtype en het gewas. Voor het berekenen van de beschikbaar van $\mathrm{K}$ zijn daarom de volgende gegevens altijd nodig.

- Bodemtype: duinzand, dekzand, zeeklei, rivierklei, maasklei, dalgrond, veen en löss

- Het landgebruik

Afhankelijk van het type landgebruik zijn de volgende gegevens nodig:

- $\quad \mathrm{K}-\mathrm{CaCl}_{2}$ (grasland, mais, bouwland): plant beschikbaar $\mathrm{K}-\mathrm{CaCl}_{2}\left(\mathrm{mg} \mathrm{kg}^{-1}\right)$

- $\quad$ CEC (grasland, bouwland) van de bodem (mmol+ $\mathrm{kg}^{-1}$ )

- Het kleigehalte (\%), OS-gehalte (\%) een $\mathrm{pH}^{-\mathrm{CaCl}_{2}}$ van bodem (bouwland).

De K-toestand van de bodem is lang gebaseerd geweest op het zogenaamde K-getal. Deze werd berekend uit de hoeveelheid $\mathrm{K}_{2} \mathrm{O}$ (gemeten via een 0,1 $\mathrm{M} \mathrm{HCl}$-extractie) met gebruikmaking van een correctiefactor $\mathrm{F}$ om te corrigeren voor de gehalten organische stof en lutum. Deze correctiefactor varieerde per grondsoort. Op basis van dit K-getal werden bodems ingedeeld in waarderingsklassen voor K-toestand. Het K-getal is ingevoerd in 1928 op basis van de waarneming dat een humusrijke grond meer $\mathrm{K}$ bevatte dan een humusarme grond. Hierbij werd echter geen rekening gehouden met andere bodemfactoren en andere nutriënten in de bodem die effect hebben op de beschikbaarheid van kalium (Den Boer et al. 2010). Recent onderzoek laat zien dat het K-getal slecht samenhangt met de gewasrespons (Van Rotterdam-Los, 2010, Bussink et al. 2011). De reden is dat de koppeling van Kbeschikbaarheid aan humus (alleen) geen rekening houdt met de verdeling van $\mathrm{K}$ over de verschillende fracties in de bodem (Den Boer et al. 2010, Bussink et al. 2011).

Voor bepaling van het K-leverend vermogen van de bodem wordt internationaal veelal gebruik gemaakt van de concepten intensiteit, capaciteit en buffering van de bodem (van Rotterdam-Los, 2010):

- De intensiteit is de hoeveelheid $\mathrm{K}$ die in direct opneembare vorm beschikbaar is. Deze hoeveelheid is lager dan de behoefte van het gewas over het groeiseizoen.

- De capaciteit is de hoeveelheid die nageleverd kan worden vanuit de niet direct opneembare bronnen in de bodem. Daarbij is zowel de hoeveelheid als de snelheid van nalevering van belang. Op zandgronden wordt de capaciteit grotendeels bepaald door K-uitwisselbaar. 
Zandgronden bevatten weinig klei, zodat de hoeveelheid K-gefixeerd verwaarloosbaar is. Op kleigronden vindt gedurende het groeiseizoen ook nalevering vanuit $\mathrm{K}$-gefixeerd plaats.

- Buffering geeft het vermogen weer om de concentratie in de oplossing constant te houden.

Uit proeven blijkt dat het kwantificeren van de buffercapaciteit van gronden inderdaad zorgt voor een betere relatie met gewasopname (Van Schöll et al., 2019). De afgelopen jaren zijn de landbouwkundige adviezen daarom afgestapt van het K-getal en wordt er overgeschakeld naar een methode waarmee de intensiteit (op korte termijn beschikbaar) en de capaciteit (op langere termijn beschikbaar) kan worden bepaald. De omvang en sterkte van het adsorptiecomplex bepaalt in grote mate de capaciteit en buffering van $\mathrm{K}$ in de bodemoplossing. Zowel Van Rotterdam-Los (2010) als Ehlert et al. (1998) vonden dat een extractie met $0,01 \mathrm{CaCl}_{2}$ een goede indicatie was voor de $\mathrm{K}$-intensiteit.

Voor grasland is het $\mathrm{K}$-getal als basis van de bemestingsadviezen vervangen door een combinatie van $\mathrm{K}-\mathrm{CaCl}_{2}$ en $\mathrm{CEC}$ (Bussink et al. 2014, CBGV 2021). Bij een hoge CEC wordt $\mathrm{K}$ sterker gebufferd dan bij een lage $\mathrm{CEC}$. Bij een hoge $\mathrm{CEC}$ en een lage $\mathrm{K}-\mathrm{CaCl}_{2}$ is er dan een hogere kali-bemestingsgift nodig om eenzelfde opbrengstrespons te generen als bij een lage $\mathrm{CEC}$ en lage $\mathrm{K}-\mathrm{CaCl}_{2}$. Uit het nieuwe bemestingsadvies kan het effect van de $\mathrm{K}$-beschikbaarheid vanuit de bodem worden afgeleid als een functie van de bodemanalyses $\mathrm{K}-\mathrm{CaCl}_{2}$ en $\mathrm{CEC}$. Hiermee kan een $\mathrm{K}$-beschikbaarheidsindex (KBI) worden berekend, waarbij de CEC is gemaximaliseerd op een waarde van $400 \mathrm{mmol}+\mathrm{kg}^{-1}$ :

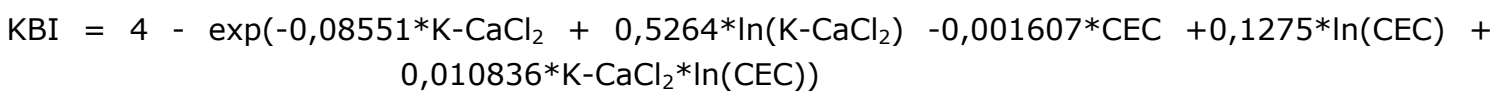

Ook voor mais is een nieuw K-bemestingsadvies op basis van bodemparameters ontwikkeld. Daarbij wordt het $\mathrm{K}$-getal vervangen door $\mathrm{K}-\mathrm{CaCl}_{2}$ (CBGV 2021, Holshof et al 2019). Anders dan bij grasland speelt de CEC geen belangrijke rol voor de gewasvoorziening met kalium. Tot een $\mathrm{K}-\mathrm{CaCl}_{2}$ van 60 wordt er een positief effect van bemesting op de K-opname of opbrengst gevonden (Holshof et al 2019). Bij een gangbare bemesting met dierlijke mest is er overigens geen effect van $\mathrm{K}-\mathrm{CaCl}_{2}$ op de opbrengst, ofwel: een lage K-beschikbaarheid vanuit de bodem kan volledig gecompenseerd worden door een goed uitgevoerde bemesting. Bij het nieuwe bemestingsadvies wordt op basis van onttrekking geadviseerd. Daarbij wordt er vanaf $\mathrm{K}-\mathrm{CaCl}_{2}$ van $60 \mathrm{mg} / \mathrm{kg}$ gecorrigeerd voor de K-bodemtoestand.

- $\mathrm{Bij}$ een $\mathrm{K}-\mathrm{CaCl}_{2}<60$ is de $\mathrm{K}$-beschikbaarheid onvoldoende voor gewasgroei, aanvullende bemesting is nodig.

- $\quad \mathrm{Bij} \mathrm{K-CaCl}>60$ is de $\mathrm{K}$-beschikbaarheid voldoende voor gewasgroei, maar niet toereikend om de gewasonttrekking volledig te compenseren.

- Vanaf $\mathrm{K}-\mathrm{CaCl}_{2} 120$ is de K-beschikbaarheid voldoende om de gewasonttrekking te compenseren (Holshof et al. 2019). Een aanvullende bemesting is niet nodig

De indeling in waarderingsklassen voor de $\mathrm{K}$-toestand is hiermee voor mais komen te vervallen. Uit dit advies kan het effect van de $\mathrm{K}$-beschikbaarheid vanuit de bodem worden afgeleid van hoeveelheid $\mathrm{K}$ $\mathrm{CaCl}_{2}$. De K-beschikbaarheidsindex (KBI) voor mais wordt dan als volgt berekend:

$\mathrm{KBI}=\left(1-\left(120-\mathrm{K}-\mathrm{CaCl}_{2}\right) / 120\right) \times 2,5$

Waarbij $\mathrm{K}-\mathrm{CaCl}_{2}$ wordt gemaximeerd op 120 en geschaald met 2,5 om qua eenheid vergelijkbaar te zijn met grasland.

Op bouwland is het $\mathrm{K}$-getal in de bemestingsadviezen nog niet vervangen door een combinatie van $\mathrm{K}$ $\mathrm{CaCl}_{2}$ en $\mathrm{CEC}$. Een afleiding van de $\mathrm{K}$-toestand op basis van bodemparameters $\mathrm{K}-\mathrm{CaCl}_{2}$ en $\mathrm{K}-\mathrm{CEC}$ is wel uitgevoerd door Ros en Bussink (2011). Daarbij werd een verschil gevonden tussen zand- en kleigronden. Voor zandgronden kan de K-beschikbaarheid daarbij worden voorspeld met $\mathrm{K}-\mathrm{CaCl}_{2}$ (intensiteit). Voor kleigronden geeft K-CEC (K-bezetting aan de CEC) de potentiële beschikbaarheid weer en deze is per definitie veel hoger dan $\mathrm{K}-\mathrm{CaCl}_{2}$ (intensiteit). De nauwkeurigheid van de meting van $\mathrm{K}-$ CEC is echter nog onvoldoende om daar de K-beschikbaarheid vanuit af te kunnen leiden. Daarom wordt gekozen voor een afleiding van de $\mathrm{K}$-beschikbaarheid op basis van zowel $\mathrm{K}-\mathrm{CaCl}_{2}$ als $\mathrm{CEC}$.

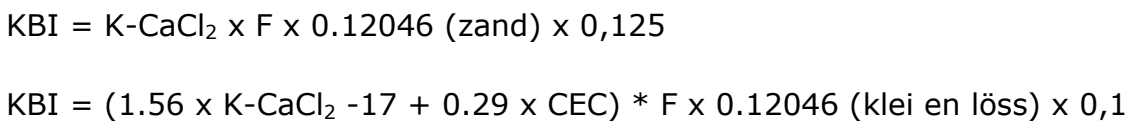


Het effect van grondsoort, organische stof en lutum wordt daarbij nog meegewogen door de correctiefactor $\mathrm{F}$ op te nemen in de formule. De correctiefactor $\mathrm{F}$ is afkomstig uit de berekening van het K-getal (CBGV, 2002) en wordt mede beïnvloed door de pH en het kleigehalte. De factoren 0,125 voor zand en 0,10 voor klei en lössgrond zijn toegevoegd om de KBI op een vergelijkbare schaal te normaliseren als grasland en mais.

Voor grasland en mais wordt de K-beschikbaarheid worden gewaardeerd op basis van een K-beschikbaarheids-index (KBI) als afgeleid van het nieuwe K-bemestingsadvies (Tabel 2.2).

Tabel 2.2 Beoordeling kaliumtoestand en beschikbaarheid. KBI-bouwland nog voorlopig afhankelijk van invulling kalibodemadvies CBAV.

\begin{tabular}{|c|c|c|c|}
\hline Kaliumtoestand & KBI-gras & KBI-mais & KBI-bouwland \\
\hline Zeer laag & $<1.5$ & - & - \\
\hline Laag & $1.5-2.5$ & $<2.5$ & $<1.3$ \\
\hline Ruim voldoende & - & - & $1.6-2.0$ \\
\hline Hoog & $4.0-4.8$ & $>4.0$ & $2.0-3.0$ \\
\hline
\end{tabular}

\subsection{Het stikstofleverend vermogen}

Stikstof is het nutriënt dat planten het meeste nodig hebben en dat veelal als eerste beperkend is voor de groei. Planten nemen stikstof op in minerale vorm als nitraat en ammonium. Stikstof is in de bodem echter grotendeels in organische verbindingen aanwezig. De beschikbaarheid van $\mathrm{N}$ voor planten gedurende het groeiseizoen is daarmee afhankelijk van de omvang en snelheid van mineralisatie uit de aanwezige organische stof.

Voor het voorspellen van de hoeveelheid stikstof die gedurende het groeiseizoen beschikbaar komt voor het gewas zijn meerdere benaderingen mogelijk.

- Afleiding van bodemchemische bepalingen ( $\mathrm{N}$-totaal, DON, Nmin, etc) waarbij een chemische analyse gekoppeld is aan metingen van de mineralisatiesnelheid in het laboratorium of het veld. Dit levert een empirische relatie op gebaseerd op meerjarige proeven.

- Afleiding van laboratoriumbepalingen aan activiteit van bodemleven. Dit is een biologische 'incubatieproef' waarbij een hoeveelheid grond in het laboratorium wordt opgeslagen - vaak bij een constante temperatuur en vochtgehalte - waarbij vervolgens de toename in nitraat over een vooraf bepaalde periode wordt gemeten.

- Vuistregels (bijv. afbraak van organische stof met $2 \%$ per jaar).

- $\quad$ Eenvoudige modellen gebaseerd op enkele variabelen zoals bijvoorbeeld het mineralisatiemodel MINIP dat in Nederland veel gebruikt wordt. Dit model voorspelt de afbraak van organische stof en het daaraan gekoppelde N-levering aan de hand van het percentage organische stof, de koolstof-stikstofratio en een parameter die de kwaliteit van de organische stof beschrijft (in dit geval een zogenoemde 'initiële leeftijd' : organische stof met een jonge leeftijd breekt sneller af dan oude organische stof).

- Complexe modellen waarmee de stikstoflevering kan worden voorspeld in afhankelijkheid van allerlei bodemkundige factoren die het afbraakproces in de bodem beïnvloeden. Denk bijvoorbeeld aan modellen als ANIMO, NDICEA, en N-wheat, etc. Deze modellen voorspellen de afbraak van organische stof in relatie tot de hoeveelheid en kwaliteit van verschillende organische stofpools en het weer.

$\mathrm{Er}$ is en wordt zeer veel onderzoek gedaan naar de $\mathrm{N}$-mineralisatie en de mogelijkheden om deze te voorspellen (Ros, 2011). Eenvoudige benaderingen hebben als nadeel dat ze de complexiteit van de bodem onvoldoende meewegen, waardoor de schattingen grof en weinig toegesneden zijn op perceelsniveau. De meer complexe benaderingen wegen wel veel factoren mee maar hebben als nadeel dat er veel aannames en schattingen gedaan moeten worden omdat betrouwbare metingen voor een groot 
aantal relevante invoerparameters ontbreken, wat veel onzekerheid en ruis rond de uitkomsten oplevert. Complexe modellen leveren daardoor geen betrouwbaarder uitkomsten dan eenvoudige modellen.

De capaciteit van de bodem om stikstof te leveren wordt ook wel het N-leverend vermogen (NLV) van de bodem genoemd. Het is een inschatting van de meerjarig gemiddelde NLV. Hoe deze stikstof gedurende het seizoen vrijkomt is cruciaal voor een goed bemestingsadvies (Ros \& Bussink, 2013), maar minder relevant voor de bodemkwaliteit als zodanig. Daarom wordt het effect van weer vooralsnog niet meegenomen in de bodembeoordeling. De N-levering wordt voor grasland en bouwland verschillend berekend omdat er voor grasland in het verleden honderden proeven zijn uitgevoerd om grip te krijgen op het vermogen van een bodem om stikstof te leveren. Voor bouwland is dit veel minder het geval. Voor grasland wordt daarom uitgegaan van de berekening conform de Bemestingsadviesbasis (CBGV, 2021). Voor de akkerbouw wordt de NLV berekend met het mineralisatiemodel MINIP (Janssen 1984).

Voor het berekenen van de $\mathrm{N}$-levering is de volgende informatie nodig:

- landgebruik: grasland/bouwland

- bodemtype: duinzand/dekzand/zeeklei/rivierklei/maasklei/dalgrond/klei/veen/löss

- $\quad$ grasland: $\mathrm{N}$-totaalgehalte in bodem $\left(\mathrm{g} \mathrm{N} \mathrm{kg}^{-1}\right)$ en leeftijd van grasmat (jaar)

- bouwland: C:N ratio van bodem (-), C-organisch (\%) en organisch stofgehalte (\%)

Bij grasland wordt uitgegaan van een relatie tussen $\mathrm{N}$-organisch (of $\mathrm{N}$-totaal: het verschil tussen $\mathrm{N}$ organisch en N-totaal is namelijk verwaarloosbaar) en het NLV (Tabel 2.3), grotendeels gebaseerd op onderzoek van Hassink (1995). Daarbij wordt nog een uitsplitsing gemaakt naar klei- en zandgronden en veen (inclusief zandig en kleiig veen). Ook wordt er rekening gehouden met de leeftijd van de graszode. De oorspronkelijke formule is vastgesteld voor een bemonsteringsdiepte van $20 \mathrm{~cm}$. Omdat er bij grasland veelal op $10 \mathrm{~cm}$ wordt bemonsterd is er begin jaren 2000 een afleiding gemaakt voor bemonsterings-diepte op $10 \mathrm{~cm}$. De totale NLV is gemaximeerd op $200 \mathrm{~kg} \mathrm{~N} \mathrm{ha}^{-1} \mathrm{jr}^{-1}$ op zand en $250 \mathrm{~kg}$ $\mathrm{N} \mathrm{ha}{ }^{-1} \mathrm{jr}^{-1}$ op klei. Als de leeftijd van de graszode bekend is kan de NLV-voorspelling worden verbeterd (zie Adviesbasis, CBGV, 2021).

Tabel 2.3 Berekening van NLV ( $\left.\mathrm{kg} \mathrm{ha}^{-1}\right)$ op zand, klei en veen op grasland (CBGV, 2021).

\begin{tabular}{lccl} 
NLV & monsterdiepte & NLV functie & a-waarde \\
zand & $0-20$ & $78,0+\mathrm{a} \times(\mathrm{g}$ Norg $/ \mathrm{kg}$ grond $)$ & 31.2 \\
\hline & $0-10$ & $78,0+\mathrm{a} \times(\mathrm{g} \mathrm{Norg} / \mathrm{kg}$ grond $) \wedge 1,0046$ & 28.4 \\
\hline Klei & $0-20$ & $31,7+\mathrm{a} \times(\mathrm{g}$ Norg $/ \mathrm{kg}$ grond $)$ & 34.8 \\
\hline & $0-10$ & $31,7+\mathrm{a} \times(\mathrm{g} \text { Norg } / \mathrm{kg} \text { grond })^{\wedge} 1,0046$ & 36.6 \\
\hline veen & $0-10$ & 250 & \\
\hline
\end{tabular}

Voor bouwland wordt de NLV gebaseerd op MINIP-berekeningen (Janssen, 1984, 1996, 2002). In de bemestingsadviesbasis voor akkerbouw wordt geen afleiding gegeven voor NLV. In onderzoek wordt MINIP wel gebruikt voor het voorspellen van de NLV, bijvoorbeeld in het project Telen met Toekomst (Postma 2002, Postma en Van Dijk, 2004a,b; Van Dijk et al. 2009). Essentie van het rekenmodel MINIP is dat alle soorten organische stof op vergelijkbare wijze worden afgebroken, maar dat de ene soort organische stof (bodem, gewasresten, organische meststoffen) gevoeliger is voor afbraak dan de andere. Voor de gevoeligheid aan het begin van het afbraakproces is het concept van de a-waarde ('apparent initial age') geïntroduceerd. In de loop der tijd neemt de gevoeligheid voor afbraak af. Voor de a-waarde bodemorganische stof wordt onderscheid gemaakt naar grondsoort. Daarnaast wordt de afbraaksnelheid beïnvloed door de temperatuur. De mineralisatie van stikstof is gekoppeld aan de decompositie van organische stof, waarbij rekening wordt gehouden met de $\mathrm{C}: \mathrm{N}$ ratio van het organisch materiaal en assimilatie door de micro-organismen. In MINIP wordt de decompositie berekend op jaarbasis. Voor de berekening van de NLV wordt hier een afbakening gemaakt tot de periode aprilaugustus (groeiseizoen). Grondsoorten worden hierbij ingedeeld in groepen met elk een eigen a-waarde voor 'schijnbare leeftijd' of kwaliteit van de organische stof:

- $\quad$ Duinzandgrond, met a-waarde van 14,3

- Kleiig veen, met a-waarde van 35

- Overige grondsoorten, met a-waarde van 20. 
De hoeveelheid C-organisch in $\mathrm{kg}$ per hectare wordt berekend uit de bulkdichtheid en het C-gehalte (\%), uitgaande van een bouwvoor van $25 \mathrm{~cm}$.

Er zijn in Nederland geen waarderingsklassen voor de NLV van de bodem. Het agrarisch laboratorium Eurofins Agro geeft een streeftraject voor NLV tussen 95-145 kg N ha-1 voor grasland en bouwland. In bodemwaarderingssystemen zoals CASH (Moebius-Clune et al., 2016), SINDI (Sparling et al., 2008) of SMAF (Andrews et al., 2004) wordt de NLV niet gebruikt als indicator. In SINDI wordt wel de N-totaal gebruikt voor grasland. Daarbij wordt voor de waardering voor productiedoeleinden een meer-is-beter curve gebruikt. Omdat het NLV positief gecorreleerd is aan het N-totaalgehalte van de bodem in zowel grasland- als bouwlandpercelen, kan ook hier gebruik worden gemaakt van dezelfde systematiek. We stellen daarom een optimum voor van $100 \mathrm{~kg} \mathrm{~N} \mathrm{ha}^{-1}$ voor bouwland en $140 \mathrm{~kg} \mathrm{~N} \mathrm{ha}^{-1}$ voor grasland.

In 2018 zijn de beschikbare adviessystemen voor stikstofbemesting in relatie tot het $\mathrm{N}$-leverend vermogen van de bodem geëvalueerd voor de akkerbouwsector (Postma et al., 2018). Hieruit wordt geconcludeerd dat het zinvol is om een adviessysteem te ontwikkelen gebruik makend van de balansmethode, waarbij rekening wordt gehouden met het NLV van percelen. Er wordt geen aanbeveling gedaan voor een specifieke methode, maar het wordt aanbevolen om dit in een vervolgtraject uit te zoeken.

\subsection{Het watervasthoudend vermogen}

De beschikbaarheid van water gedurende het groeiseizoen is van groot belang voor de gewasproductie. De waterbeschikbaarheid in de bodem wordt grotendeels bepaald door de waterretentiekarakteristiek. Sommige bodems kunnen namelijk beter water vasthouden dan andere. Zo kunnen organische stofrijke bodems relatief meer water vasthouden dan organische stofarme bodems, en kunnen kleigronden water efficiënter vasthouden dan zandgronden. Een volledige beschrijving van de beschikbaarheid van water in de bodem vraagt om de kwantificering van twee verschillende grootheden: de hoeveelheid water per eenheid van massa of volume van de bodem (ook het vochtgehalte genoemd) als ook de energietoestand (ook wel de potentiaal van het bodemwater genoemd) van het water in de bodem. Beide factoren zijn van het grootste belang voor de plantengroei. Het vochtgehalte alleen zegt niet altijd iets over de beschikbaarheid ervan voor gewasopname. Het vochtgehalte vertelt alleen hoeveel water er aanwezig is in de bodem. De potentiaal van het bodemwater wordt gedefinieerd als de energie die nodig is om het water uit de bodem te kunnen verdrijven. Deze potentiaal geeft ons ook niet direct inzicht in de hoeveelheid water die beschikbaar is voor planten. Beide kenmerken zijn nodig. Beide grootheden zijn ook aan elkaar gerelateerd; de waterretentiecurve ( $p F-c u r v e)$ is een grafische voorstelling van deze verhouding.

De vochtkarakteristiek van een bodem is afhankelijk van zijn fysische eigenschappen, textuur en structuur. Bodemtextuur verwijst naar de korrelgrootteverdeling. De textuur van een bodem wordt bepaald door het gehalte aan klei, leem en zand. Bovendien bevatten bijna alle bodems organische stof. De fijne bodemdeeltjes dragen samen met het organische stof bij aan aggregaatvorming (en daarmee ook de bodemstructuur). De grootte, de vorm en de schikking van de bodemdeeltjes en aggregaten, en de daardoor gevormde leegtes, bepalen de capaciteit van de bodem om water vast te houden. Grote poriën zijn in staat om meer water sneller te geleiden dan kleine poriën en bovendien zal het verwijderen van water uit grote poriën makkelijker zijn en minder energie vragen dan wanneer men water uit kleine poriën wil verdrijven. Als een bodem op veldcapaciteit is, dan is de vochttoestand zodanig dat al het water uit de macroporiën vervangen is door lucht onder invloed van de zwaartekrachtpotentiaal. Het water dat nog in de bodem aanwezig is, wordt vastgehouden in microporiën. De heersende potentiaal bij veldcapaciteit kan variëren van bodem tot bodem maar schommelt meestal tussen $-0,1$ bar (zandgrond) tot $-0,3$ bar (leemgrond). Als het water zo sterk wordt vastgehouden dat het niet meer beschikbaar is voor gewasopname dan spreekt men over het verwelkingspunt. Het water bevindt zich voornamelijk als film rond individuele bodemdeeltjes. De potentiaal onder deze omstandigheden ligt rond de -18 bar. De hoeveelheid vocht aanwezig tussen de veldcapaciteit en het verwelkingspunt wordt gedefinieerd als de hoeveelheid plant-beschikbaar water.

De recente reviewstudie van allerlei bodemwaarderingsconcepten (Buneman et al., 2016) benoemt indicatoren die gebruikt kunnen worden om meer zicht te krijgen op het watervasthoudend vermogen 
van een bodem. Veel gebruikte indicatoren zijn de hoeveelheid plant beschikbaar water (14x), de vloeigrens en porositeit (beide $11 x$ ), het vochtgehalte bij veldcapaciteit $(11 x)$ en de verzadigde doorlatendheid (10x). Voor de bodemmaatlat wordt gebruikt gemaakt van de indicator plant beschikbaar water om inzicht te geven in verschillen in waterbeschikbaarheid tussen percelen.

Het watervasthoudend vermogen kan het best worden gemeten in het lab. Als het niet mogelijk is, kunnen de parameters van de waterretentiecurve geschat worden op basis van de textuur (zand, klei en siltgehalte) als ook het gehalte aan organische stof. Hiervoor wordt gebruik gemaakt van empirische relaties (zogenoemde pedotransferfuncties, ptf) die ontwikkeld zijn op duizenden bodemanalyses waar zowel de pF-curve als ook de basis bodemeigenschappen zijn gemeten. Om de vochtretentiekarakteristiek van de bodem te berekenen op basis van een pedotransferfunctie (Ros et al., 2019) is info nodig van het kleigehalte (\%), zandgehalte (\%), siltgehalte (\%) en het gehalte organische stof (\%).

De waterretentiecurve van van Genuchten (1980) wordt bepaald door 4 parameters: het verzadigde watergehalte $\left(\theta_{\text {sat }}\right)$, het restwatergehalte $\left(\theta_{\text {res }}\right)$, en de paramaters a en $n$. Hier gebruiken we de ptf van Wösten et al (1999). Deze PTF biedt ononderbroken schattingen van waterretentieparameters op basis van de bodemtextuur en het organische stofgehalte, en is afgeleid van de Europese bodemdatabase HYPRES.

\subsection{Ondersteunende bodemkenmerken}

\subsubsection{Textuur}

In de BLN, versie 1.0 zijn referentiewaarden vastgesteld voor enkele combinaties van landgebruik en bodemtype waaronder akkerbouw en melkveehouderij op klei en zand. In de toekomst zal een verdere verfijning worden gemaakt binnen de hoofdgrondsoorten. Binnen het bodemwaarderingssysteem van de OBI wordt rekening gehouden met de landbouwkundige grondsoorten zoals die gebruikt worden in het landbouwkundig onderzoek. Het landbouwkundige bodemtype is afgeleid van de Bodemkaart 1:50.000 en wordt vertaald in één van de zeven landbouwkundige bodemtypes: zeeklei, rivierklei, dekzand, duinzand, dalgrond, veen en löss. Deze landbouwkundige bodemtypes zijn nodig om een koppeling te leggen met de vele agronomische veldproeven die op een specifieke grondsoort zijn uitgevoerd.

Textuur als zodanig is niet of nauwelijks te beïnvloeden door bodemmanagement maar is wel bepalend voor bepaalde processen in de bodem en verklarend voor bepaalde functies die de bodem kan leveren. Zoals in voorgaande hoofdstukken is toegelicht, heeft textuur invloed op de meting en waardering van de $\mathrm{K}$-toestand, de $\mathrm{pH}$, het $\mathrm{N}$-leverend vermogen als ook het waterbergend vermogen. Op basis van openbare databronnen is van elk perceel het bodemtype, het landgebruik en de grondwaterstand bekend. Textuur hoeft dus als zodanig niet apart bepaald te worden. Omdat de meting onderdeel is van het routinematige meetpakket in agrarische laboratoria is het aan te bevelen om hier wel gebruik van te maken. Hiermee biedt het mogelijkheid tot meer maatwerk en concreter inzicht in de kwaliteit van het geanalyseerde perceel.

\subsubsection{Organische stof}

Organische stof is een cruciaal element voor een goed functionerende bodem en daarmee voor een goede gewasgroei als ook een levendige boerensloot. Het speelt een rol bij de beschikbaarheid van nutriënten en water, de vastlegging van koolstof in de bodem, bij de vorming van structuur en bij de weerbaarheid van de bodem tegen ziekten en plagen. Het verhoogt de kationenomwisselcapaciteit van de bodem (CEC) waardoor de bodem meer kationen als kalium, calcium en magnesium kan vasthouden. Organische stof zelf bevat relevante mineralen als stikstof, fosfor en zwavel, die na afbraak van de organische stof beschikbaar komen (mineraliseren).

Om deze reden is het gehalte organische stof in veel bodemfuncties een sturende variabele (Ros, 2019). Voor de in deze publicatie beschreven bodemfuncties is dat het geval voor het N-leverend vermogen, 
de $\mathrm{pH}$, het waterbergend vermogen en indirect ook bij de beoordeling van de K-toestand. Het gebruik van organische stof als directe indicator is voor toepassing in Nederland weinig zinvol.

Om het organische-stofgehalte in de bodem te handhaven, moet er evenveel effectieve organische stof (EOS) worden aangevoerd als er wordt afgebroken. De afbraaksnelheid van bodem-organische stof hangt af van diverse factoren: de aard van de organische stof, de grondsoort, het lutumgehalte, de hoogte van het organische-stofgehalte, de $\mathrm{C} / \mathrm{N}$-verhouding, de ouderdom van de organische stof, de ontwateringstoestand van het perceel en de $\mathrm{pH}$ van de grond. De optimale hoeveelheid organische stof verschilt daardoor per perceel. Niet altijd geldt: meer is beter - bijvoorbeeld wanneer er zoveel organische stof in een grond zit dat de draagkracht omlaaggaat en machines kunnen vastlopen. Een recente wereldwijde meta-analyse van Oldfield et al. (2019) laat bijvoorbeeld zien dat het positieve effect van organische stof op gewasopbrengst in de meeste langjarige proeven alleen optreedt zolang het gehalte koolstof lager is dan 1,5 tot $2 \%$. Boven de 3 á $4 \%$ organische stof heeft het verhogen van het OS-gehalte daarom weinig meerwaarde. In Nederland heeft 75\% van alle bouwland percelen een OS-gehalte hoger dan 3,2\% (Steijsiger, 2021). Voor graslanden ligt het OS-gehalte zelfs substantieel hoger. Langjarige proeven met gras en mais in Gortel waar meer dan 10 jaar enorme hoeveelheden stalmest (tot 200 ton/ha) zijn toegediend (Prins \& Brak, 1977), laten zien dat het effect van de (extra) organische stof vooral zichtbaar wordt in een hogere $\mathrm{N}$-levering. Dus het is de extra stikstof die zorgt voor een eventuele verhoging van de gewasopbrengst en niet zozeer de organische stof (Heijbeek, 2017). Een analyse van langjarige proefgegevens in Duitsland door Körschens et al. (2005) laat zien dat voor een optimale gewasopbrengst een organisch stofgehalte van 1,5 á $2 \%$ voldoende is. Een jaarlijkse gift van 20 tot 35 ton drijfmest (of vergelijkbare stalmest) bleek voldoende om het bodemleven op peil te houden.

De kwaliteit van organische stof is veelzijdig en kan op verschillende manieren worden aangeduid, bijvoorbeeld met stabiliteit, leeftijd (jong of oud) en $\mathrm{C} / \mathrm{N}$-verhouding. Voor een goede bodemvruchtbaarheid zijn alle kwaliteiten van organische stof belangrijk. Een goede bodemkwaliteit ontstaat door een goede fysische (structuur), chemische (nutriëntenvoorziening) en biologische (bodemleven) bodemvruchtbaarheid. Ze worden alle drie door organische stof verbeterd, op basis van verschillende kwaliteiten van de organische stof. Welke kwaliteiten het meest relevant zijn, hangt af van wat men van de organische stof verwacht c.q. met welk doel men het toedient. Is het doel om het organischestofgehalte van de bodem te handhaven of te verhogen, dan moet men voldoende effectieve organische stof aanvoeren om tenminste de afbraak in de bodem de compenseren. Met name aanvoer van stabiele organische stof draagt hiertoe bij. Verhoging van de hoeveelheid organische stof in de bodem verbetert de verkruimelbaarheid van kleigrond, vermindert de slempgevoeligheid van lichte zavel, zorgt voor meer buffering van vocht in de bodem en verhoogt de capaciteit van de bodem om kationen vasthouden en uit te wisselen. Voor de structuurstabiliteit op zand- en dalgrond en het tegengaan van verstuiving is een regelmatige toevoer van verse organische stof noodzakelijk. Een hoge nutriëntenlevering door mineralisatie uit de organische stof verkrijgt men door gemakkelijk afbreekbare organische stof met een lage $\mathrm{C} / \mathrm{N}$-verhouding aan te voeren en door het aandeel jonge humus ofwel voedingshumus in de bodem te verhogen. De aanvoer van verse, gemakkelijk afbreekbare organische stof stimuleert ook het bodemleven.

\subsubsection{Droge bulkdichtheid}

Voor een gezonde gewasontwikkeling zijn een goede doorluchting van de bodem en een vlotte afvoer van overtollig water belangrijk. Voor een optimale wortelgroei moet het aandeel poriën in de grond minimaal $40 \%$ bedragen en tenminste $15 \%$ van deze poriën moeten lucht bevatten. Waar hier niet aan voldaan wordt, kunnen plantenwortels minder gemakkelijk of zelfs helemaal niet groeien. Hierdoor kan de opbrengst achterblijven en kunnen planten gevoeliger worden voor droogte, ziekten en plagen. Om een intensieve en diepe beworteling, een goede afvoer van regenwater en een goede doorluchting van de bodem mogelijk te maken, moet de bodem niet te dicht zijn.

De gemeten droge bulkdichtheid is een absolute maat voor de dichtheid van de bodem. Deze eigenschap is soms ook nodig om gemeten andere (biologische) indicatoren om te rekenen naar de juiste eenheden. Het meten van de bulkdichtheid is tevens van belang indien bij het meten van de indringingsweerstand het vermoeden bestaat dat (een deel van) het bodemprofiel is verdicht. Voor zand, en lichte en matig 
zware zavel geldt een kritieke dichtheid $1.6 \mathrm{~g} \mathrm{~cm}^{-3}$; voor gronden met een lutumgehalte groter dan $17 \%$ (zware zavel- en kleigronden) geldt dat de kritieke dichtheid gelijk is aan 1.75-0.009*lutum.

Voor tuin- en bouwland met een humusgehalte lager dan 4\% en voor grasland dieper dan 10 centimeter worden de volgende streefwaarden gebruikt voor zand (Koopmans \& Brands, 2002): goede kwaliteit als dichtheid kleiner dan 1,4 en een slechte kwaliteit als dichtheid groter is dan $1,6 \mathrm{~g} \mathrm{~cm}^{-3}$. Voor zavel en klei ligt de grens voor een goede kwaliteit op $1,1 \mathrm{~g} \mathrm{~cm}^{-3}$ en de bovengrens op $1,5 \mathrm{~g} \mathrm{~cm}^{-3}$.

Wanneer het humusgehalte, uitgedrukt als gewichtspercentage, hoger is dan $4 \%$, is het beter rekening te houden met het werkelijke humusgehalte als dat bekend is, in de bovenste 10 centimeter van grasland. De graadmeter is dan de relatieve dichtheid (Dr):

$$
\operatorname{Dr}=(4,93 \times \text { humusgehalte }+63-(100 / \text { dichtheid })) /(2,15 \times \text { humusgehalte }+9) \text {. }
$$

Een bodem met een goede kwaliteit heeft een Dr-waarde kleiner dan 0.33 terwijl de dichtheid beperkend wordt als de Dr-waarde groter is dan 0.66. 


\section{$4 \quad$ Vooruitblik}

Dit rapport beschrijft de achtergronden om op basis van een paar eenduidige bodemmetingen plus beoordeling zicht te geven op de kwaliteit van de bodem in relatie tot een landbouwkundige gewenste situatie. Het gebruik van recente bodemmetingen zoals die beschikbaar zijn vanuit routinematige bodemanalyses uit agrarische laboratoria is noodzakelijk en wordt gecombineerd met beschikbare historische informatie, managementinformatie en data uit openbare bronnen. Desgewenst kan ingezoomd worden op het vaststellen van de bodemkwaliteit voor specifieke doelen of functies waarbij rekening wordt gehouden met eventuele risico's op afwenteling naar andere functies. Er wordt een totaaloverzicht gegeven van de kwaliteit van alle relevante bodemfuncties. Op basis van deze bodemkwaliteitsbeoordeling kan de gebruiker concrete maatregelen nemen om het bodembeheer te verbeteren. De daadwerkelijke koppeling met gerichte maatregelen om knelpunten op te lossen, wordt in een vervolgstudie uitgewerkt.

De Bodemmaatlat geeft inzicht in de bodemkwaliteit voor de functies die verantwoordelijk zijn voor het leveren (en bufferen) van de nutriënten stikstof, fosfaat en kalium, de zuurgraad van de bodem als ook het waterbergend vermogen van de bodem. De bodemdichtheid kan worden berekend op basis van de textuur en het organische stofgehalte, maar praktijkkennis van het perceel als ook informatie van een profielkuil is kan nodig zijn om te beoordelen of er werkelijk sprake is van bodemverdichting.

Op basis van het resultaat van dit rapport heeft de BO-Akkerbouw besloten niet verder te gaan met de ontwikkeling van de Bodemmaatlat maar aan te sluiten bij de integrale systematiek van meten en beoordelen zoals dat binnen PPS Beter Bodembeheer wordt uitgewerkt voor BLN versie 2.0 en de Open Bodemindex. De voorgestelde bodemmaatlat biedt op dit moment te weinig extra's ten opzichte van de al beschikbare tools. 


\section{Literatuur}

Andrews et al., 2004. The soil management assessment framework: A quantitative soil quality evaluation method. Soil Science Society of America Journal, 68(6), 1945-1962.

Andrews, S.S., and C.R Carroll, 2001. Designing a soil quality assessment tool for sustainable agroecosystem management. Ecological Applications, 11(6), 1573-1585.

Andrews, S.S., Karlen, D.L., and C.A. Cambardella, 2004. The soil management assessment framework: A quantitative soil quality evaluation method. Soil Science Society of America Journal, 68(6), 19451962.

Andrews, S.S., Karlen, D.L., and J.P. Mitchell, 2002. A comparison of soil quality indexing methods for vegetable production systems in Northern California. Agriculture, Ecosystems \& Environment, 90(1), 25-45.

Bünemann et al., 2016. Concepts and indicators of soil quality - a review.

Karlen, D.L., Andrews, S.S., and J.W. Doran, 2001. Soil quality: Current concepts and applications. Advances in Agronomy, Vol 74, 74, 1-40.

Karlen, D.L., Ditzler, C.A., and S.S. Andrews, 2003. Soil quality: why and how? Geoderma, 114(3-4), 145-156.

Karlen, D.L., Gardner, J.C., and M.J. Rosek, 1998. A soil quality framework for evaluating the impact of CRP. Journal of Production Agriculture, 11(1), 56-60.

Bussink D.W., Den Boer D.J. \& J. Van Middelkoop, 2011. Beschikbaarheid van kali op basis van multinutriënt extractie; analyse van een database. Gezamenlijke studie NMI en Livestock Research. NMI-Rapport 1383.N.10.

Bussink D.W., Van Schöll L., Van den Draai H., Van Middelkoop J.C. \& G. Holshof, 2014. Naar een herziening van kali-advies grasland. Gezamenlijke studie NMI en Livestock Research. NMI-Rapport 1421.N.10

CBGV, 2021. Bemestingsadvies (www.bemestingsadvies.nl)

CBAV, 2021. https://www.handboekbodemenbemesting.nl

De Haan J. \& G.H. Ros, 2019. Beoordeling Bodemkwaliteit gegeven doel. Interne notitie t.b.v. landelijk advies Nationaal Programma Lanbouwbodems, $5 \mathrm{pp}$.

Den Boer D.J., Van Middelkoop J.C. \& L. Van Schöll, 2010. Interactie tussen N en K op grasland. Herziening kali-advies gewenst? Gezamenlijke studie NMI en Livestock Research. NMI-Rapport 1347.N.09.

Ehlert P.A.I., Burgers S.L.G.E., Steenhuizen J.W., Van Lune P. \& H. Loman, 1998. De betekenis van grondonderzoek met $0.01 \mathrm{M}$ calciumchloride voor het kalium bemestingsadvies van bouwland. Rapport 87. DLO-instituut voor Agrobiologisch en bodemvruchtbaarheidsonderzoek.

Ehlert P., Middelkoop van M., Geel van W., Haan J. de \& I. Regelink, 2018. Veeljarige fosfaatproefvelden op gras- en bouwland. Syntheserapport. WUR Rapport 2906, pp 113

Hanegraaf, M., van den Elsen, E., de Haan, J., \& Visser, S., 2019. Bodemkwaliteitsbeoordeling van landbouwgronden in Nederland - indicatorset en systematiek, versie 1.0. (Rapport WPR; No. 795).

Hassink, J., 1995. Organic matter dynamics and N mineralization in grassland soils.

Heijbeek, 2017. On the role of soil organic matter for crop production in European arable farming. PhD thesis Wageningen UR, $222 \mathrm{pp}$.

Holshof G., Bussink D.W., Doppenberg G.W., van Middelkoop G.C. \& H. van Schooten, 2019. Naar een nieuw kalibemestingsadvies voor snijmaïs. Gezamenlijke studie NMI en Livestock Research. Wageningen UR Livestock Research, Livestock Research Report 1189, pp 73.

Janssen B.H., 1984. A simple method for calculating decomposition and accumulation of 'young' soil organic carbon. Plant and Soil 76, 297-304.

Janssen B.H., 1996. Nitrogen mineralization in relation to $\mathrm{C}: \mathrm{N}$ ratio and decomposability of organic materials. Plant and soil 181, 39-45.

Janssen B.H., 2002. Organic matter and soil fertility. Syllabus Sectie Bodemkwaliteit, Wageningen Universiteit.

Koopmans, C.J., L. Brands. 2002. Ondersteuning van duurzaam bodembeheer - Testkit bodemkwaliteit. Louis Bolk Instituut, Driebergen. 96 p. 
Körschens et al., 2005. Bilanzierung und Richtwerte organischer Bodensubstanz. Landbauforschung Völkenrode 55, 1-10.

Moebius-Clune et al., 2016. Comprehensive Assessment of Soil Health - The Cornell Framework, Edition 3.2, Cornell University, Geneva, NY.

Oldfield et al., 2019. Global meta-analysis of the relationship between soil organic matter and crop yields, SOIL5, 15-32.

Postma R., 2002. Organische stofopbouw en N-mineralisatie op kernbedrijven; toetsing model Janssen. Telen met Toekomst rapport OV 0203.

Postma R. \& T.A. Van Dijk, 2004a. Organische stofopbouw en N-mineralisatie op kernbedrijven; toetsing Minip met resultaten 2002 en 2003 . Telen met toekomst rapport.

Postma R. \& T.A. Van Dijk, 2004b. Organische stofopbouw en N-mineralisatie; op kernbedrijven; verfijning model MINIP. Telen met Toekomst. Wageningen Plant Research International.

Postma R., van Geel W. \& J. de Haan, 2018. Ontwikkeling nieuwe systematiek voor opstellen Nbemestingsrichtlijnen. NMI-rapport 1640.N.16.

Prins W.H. \& A. Brak, 1977. Stalmest en N-reactie grasland, Gortel, 1977, IB-verslag B322, 19 pp.

Rinot et al., 2019. Soil health assessment: a critical review of current methodologies and a proposed new approach. Science of Total Environment 648, 1484-1491.

Ros G.H., 2011. Predicting soil Nitrogen Supply; relevance of soil of extractable soil organic matter fractions. PhD thesis Wageningen University.

Ros G.H. \& D.W. Bussink, 2013. Een dynamisch N-advies. Ontwikkeling en rekenregels. NMI-rapport 1504.N.13.

Ros G.H. \& D.W. Bussink, 2011. Naar een ander K-advies op bouwland. NMI-notitie 1436.N.11 (vertrouwelijk, Blgg AgroXpertus).

Ros G.H., 2019. De Open Bodemindex 0.11. OBI rapportage, 183 pp.

Ros G.H., Y. Fujita \& M. Heinen, 2019. Waterbeschikbaarheid 0.6. OBI factsheet. 10 pp.

Ros G.H., Y. Fujita \& L. van Schöll, 2019. Stikstofleverend vermogen 0.4. OBI factsheet. 7 pp.

Sparling G., Lilburn L. \& M. Voivodic-Vukovic, 2008. Provisional targets for soil quality indicators in New Zealand / Palmerston North, N.Z. : Manaaki Whenua Press. Landcare Research Science series, ISSN 1172-269X ; no. 34 ISBN 978-0-478-09396-4.

Van Dijk T.A., Van Schöll L. \& R. Postma, 2009. N-leverend vermogen van de bodem als grondslag van differentiatie N-gebruiksnormen. NMI-rapport 1303.N.08.

Van Genuchten M Th, 1980. A closed-form equation for predicting the hydraulic conductivity of unsaturated soils. Soil Science Society of America Journal. 44 (5): 892-898 .

Van Rotterdam-Los A.M.D., 2010. The potential of soils to supply phosphorus and potassium; processes and predictions. PhD thesis Wageningen University.

Van Rotterdam, A.M.D. \& D.W. Bussink., 2016. Fosfaatstreeftoestand in de bodem voor maïs en gras. CBGV-notitie Bemestingsadvies.

Van Rotterdam D., van Schöll L., D.W. Bussink en G.H. Ros, 2020. Fosfaatbeschikbaarheid 0.6. OBI factsheet. $6 \mathrm{pp}$.

Van Schöll L., Bussink D.W. \& G.H. Ros, 2020. K-beschikbaarheid. OBI factsheet. 8 pp.

Van Schöll L., Y. Fujita \& G.H. Ros, 2019. Zuurgraad, pH 0.3. OBI factsheet, 7 pp.

Wösten, J.H.M., G.J. Veerman, W.J.M. de Groot \& J. Stolte, 2001. Waterretentie- en doorlatendheidskarakteristieken van boven- en ondergronden in Nederland: de Staringreeks Vernieuwde uitgave 2001. Alterra rapport 153, Alterra, Wageningen. 


\section{Bijlage 1 Bodemindicatoren BLN en OBI}


Tabel A1. Indicatoren BLN, versie 1.0 met selectie indicatoren voor bodemmaatlat. In blauw de beoordeelde meetmethode. Groen is geselecteerd, oranje is optioneel, rood is niet geselecteerd. De groene indicatoren zijn uitgewerkt in de Bodemmaatlat 0.1

\begin{tabular}{|c|c|c|c|c|c|c|c|c|c|c|c|c|}
\hline & $\mathrm{Nr}$ & Indicator & Eenheid & Klassieke meetmethode & $\begin{array}{l}\text { Snelle, goedkopere } \\
\text { meetmethode }\end{array}$ & Goed & Goedkoop & Snel & $\begin{array}{c}\text { Veranderbaar door } \\
\text { Management }\end{array}$ & $\begin{array}{l}\text { Streef-en } \\
\text { referentie- } \\
\text { waarden }\end{array}$ & Opmerkingen & $\begin{array}{c}\text { Tot } \\
+\end{array}$ \\
\hline \multirow{3}{*}{$\begin{array}{l}\text { के } \\
\text { के } \\
0 \\
0 \\
0\end{array}$} & 1 & $\begin{array}{l}\text { Organische stofgehalte en } \\
\text { koolstofgehalte }\end{array}$ & $\%$ & Gloeiverlies en Dumas & NIRS & ++ & ++ & ++ & - & Ref ++ & $\begin{array}{l}\text { O.s. en C-gehaltes } \\
\text { beiden in Eurofins } \\
\text { analyse }\end{array}$ & 8 \\
\hline & 2 & Stabiele fractie organische stof & $\%$ & $\begin{array}{l}\text { Oxidatie in permanganaat } \\
\text { (POXC) }\end{array}$ & n.b. & ? & $?$ & ? & $?$ & --- & Nog te experimenteel & 0 \\
\hline & 3 & $\begin{array}{l}\text { Heet water extraheerbare koolstof } \\
\text { (HWC) }\end{array}$ & $\mathrm{mg} \mathrm{kg}_{1}^{-1}, \mathrm{~g} \mathrm{ha}^{-}$ & Extractie in heet water & n.b. & +++ & + & + & + & Ref + & NIRS experimenteel & 7 \\
\hline \multirow{5}{*}{ 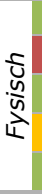 } & 4 & Watervasthoudend vermogen & $\%, \mathrm{~mm}$ & Zandbak/drukpan & o.b.v. textuur + OS & + & ++ & ++ & - & Ref + & In Eurofins analyse & 6 \\
\hline & 5 & Aggregaatstabiliteit & - & Natte zeefmethode & n.b. & ++ & - & - & $?$ & - & & 2 \\
\hline & 6 & Textuur & $\%$ & Pipetmethode & NIRS & ++ & ++ & ++ & - & Ref - & In Eurofins analyse & 6 \\
\hline & 7 & Indringingsweerstand & $\mathrm{MPa}$ & Penetrometer & & + & ++ & ++ & + & Streef + & Apparaat nodig & 8 \\
\hline & 8 & Droge bulkdichtheid & $\mathrm{kg} \mathrm{m}^{-3}$ & Massa na drogen $105^{\circ} \mathrm{C}$ & Berekend uit OS\% & + & ++ & ++ & - & Streef + & Met Eurofins analyse & 7 \\
\hline \multirow{5}{*}{ 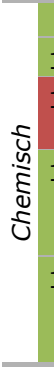 } & 9 & Zuurgraad (pH) & - & Extractie in $\mathrm{CaCl}_{2}$ & & +++ & ++ & ++ & ++ & Streef ++ & In Eurofins analyse & 13 \\
\hline & 10 & $\mathrm{~N}$-totaal & $\mathrm{g} \mathrm{kg}^{-1}, \mathrm{~kg} \mathrm{ha}^{-1}$ & Kjeldahl & NIRS & + & ++ & ++ & - & Ref ++ & In Eurofins analyse & 7 \\
\hline & 11 & $\begin{array}{l}\text { Potentieel mineraliseerbare } \\
\text { stikstof (PMN) }\end{array}$ & $\underset{1}{\mathrm{mg} \mathrm{kg}^{-1}, \mathrm{~g} \mathrm{ha}^{-}}$ & Anaerobe incubatie & NIRS & +++ & - & - & + & Ref + & NIRS experimenteel & 5 \\
\hline & 12 & Fosfaatstatus $^{3}$ & 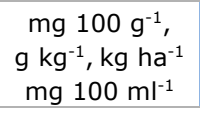 & $\begin{array}{l}\text { Extractie in ammoniumlactaat- } \\
\text { azijnzuur, } \mathrm{CaCl}_{2} \text { resp. water }\end{array}$ & NIRS & +++ & ++ & ++ & ++ & Streef ++ & In Eurofins analyse & 13 \\
\hline & 13 & Kalistatus ${ }^{3}$ & $\begin{array}{c}\mathrm{mg} 100 \mathrm{~g}^{-1} \\
\mathrm{mmol}^{+} / \mathrm{kg}^{\prime} \\
\mathrm{g} \mathrm{kg}^{-1}, \mathrm{~kg} \mathrm{ha}^{-1}\end{array}$ & Extractie in $\mathrm{HCl}$ en oxaalzuur & $\begin{array}{c}\text { NIRS }+\underset{\text { Extractie in }}{\mathrm{CaCl}_{2}}\end{array}$ & ++ & ++ & ++ & ++ & Streef ++ & In Eurofins analyse & 13 \\
\hline \multirow{3}{*}{ 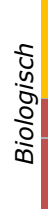 } & 14 & $\begin{array}{l}\text { Aaltjes diversiteit en aantallen } \\
\text { (incl. plantparasitaire aaltjes) }\end{array}$ & $\begin{array}{l}\text { Aantal taxa } \\
\# 100 \mathrm{ml}^{-1} \\
\text { grond }\end{array}$ & Microscopie & PCR & +++ & - & - & ++ & Streef ++ & $\begin{array}{l}\text { Alleen plantparasitair, } \\
\text { aaltjes totaal rood }\end{array}$ & 9 \\
\hline & 15 & Bacterie- en schimmelbiomassa & $\mu \mathrm{kg}^{-1}$ & PLFA & NIRS & - & + & + & - & Ref + & & 3 \\
\hline & 16 & $\begin{array}{l}\text { Regenwormen aantallen en } \\
\text { diversiteit }\end{array}$ & $\# \mathrm{~m}^{-2}, \mathrm{~kg} \mathrm{~m}^{-2}$ & Visueel & n.b. & +++ & - & - & + & Ref + & & 5 \\
\hline$\frac{\pi}{4}$ & 17 & $\begin{array}{l}\text { Visuele beoordeling (fysisch- } \\
\text { chemisch-biologisch) }\end{array}$ & Divers & Visueel & n.b. & ++ & + & - & + & Streef + & & 6 \\
\hline
\end{tabular}

In laatste kolom zijn alle plusjes opgeteld waarbij de plusjes voor streefwaarden dubbel zijn geteld. Dit geeft een indicatie van een totaal beoordeling weer. 


\section{Welke bodemfuncties / indicatoren in OBI}

situatie februari 2021, met focus op de landbouwkundige kwaliteit

Chemie \& nutriënten
- N-levering
- S-levering
- K-beschikbaarheid
- P-beschikbaarheid
- Mg-beschikbaarheid
- Cu-beschikbaarheid
- Zn-beschikbaarheid
- pH
- kationbuffering
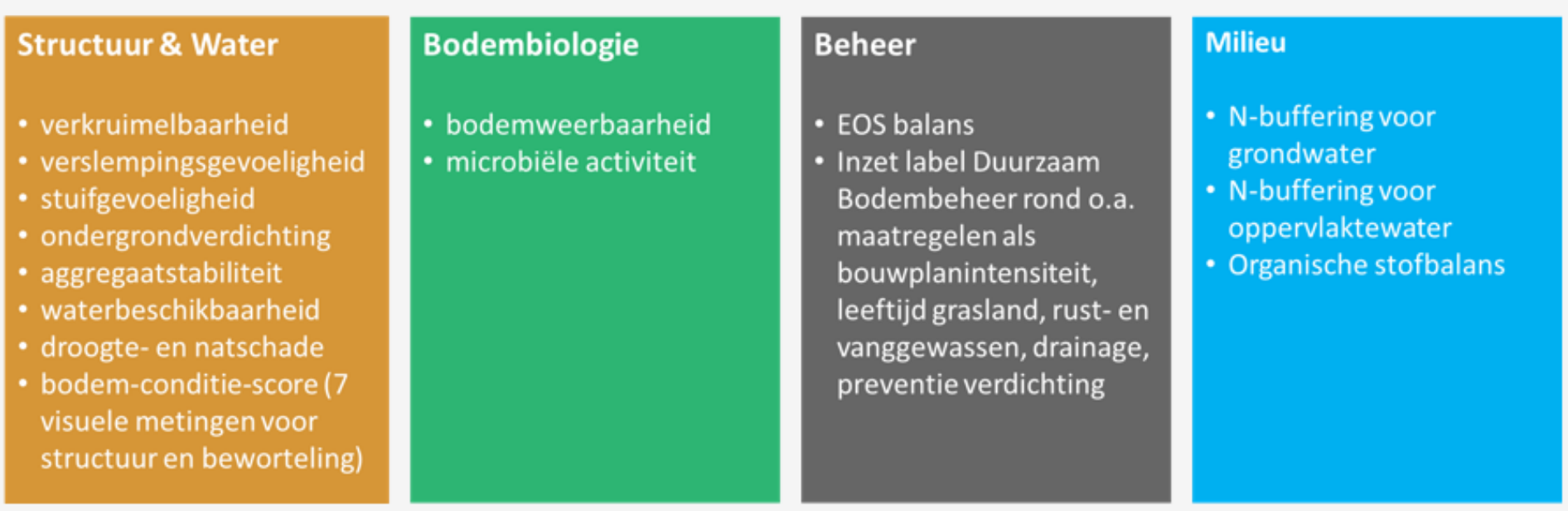

OPEN 


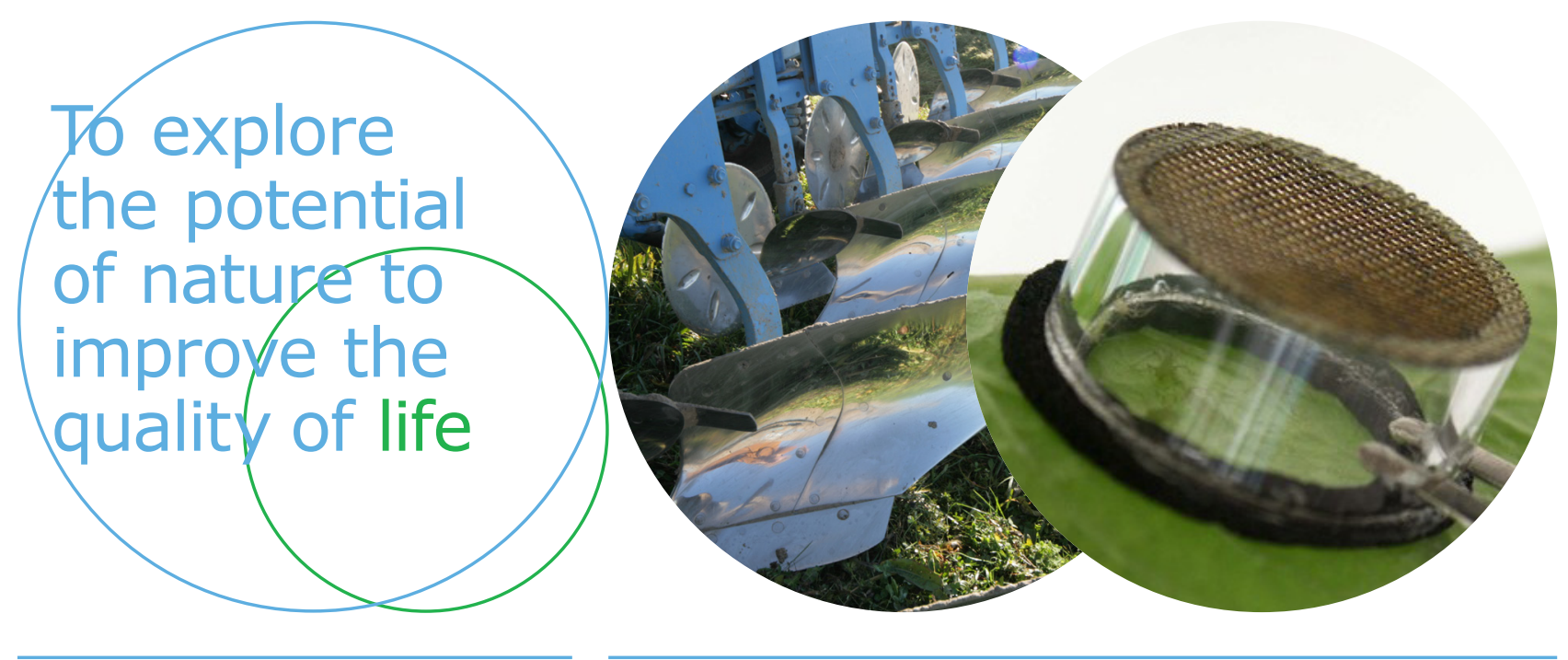

Correspondentie adres voor dit rapport: Wageningen University \& Research | Open Teelten

Edelhertweg 1

Postbus 430

8200 AK Lelystad

T (+31)320 291111

www.wur.nI/openteelten

Rapport WPR-892
De missie van Wageningen University \& Research is 'To explore the potential of nature to improve the quality of life'. Binnen Wageningen University \& Research bundelen 9 gespecialiseerde onderzoeksinstituten van stichting DLO en Wageningen University hun krachten om bij te dragen aan de oplossing van belangrijke vragen in het domein van gezonde voeding en leefomgeving. Met ongeveer 30 vestigingen, 6.000 medewerkers en 9.000 studenten behoort Wageningen University \& Research wereldwijd tot de aansprekende kennisinstellingen binnen haar domein.

De integrale benadering van de vraagstukken en de samenwerking tussen verschillende disciplines vormen het hart van de unieke Wageningen aanpak. 